\title{
Localised heating and intensive magmatic conditions prior to the 22-23 April 2015 Calbuco volcano eruption (Southern Chile)
}

\author{
Eduardo Morgado 1,2 (D) Daniel J. Morgan ${ }^{1}$ - Jason Harvey ${ }^{1} \cdot$ Miguel-Ángel Parada ${ }^{2,3}$ - Angelo Castruccio ${ }^{2,3}$. \\ Raimundo Brahm ${ }^{2,3,4} \cdot$ Francisco Gutiérrez $^{5} \cdot$ Bogomil Georgiev $^{1} \cdot$ Samantha J. Hammond ${ }^{6}$
}

Received: 6 August 2018 / Accepted: 20 February 2019 / Published online: 13 March 2019

(C) The Author(s) 2019

\begin{abstract}
Calbuco volcano is a Late Pleistocene composite stratovolcano and member of the Southern Volcanic Zone of the Chilean Andes $\left(41^{\circ} 19^{\prime} \mathrm{S}, 72^{\circ} 36^{\prime} \mathrm{W}\right)$. It lies $\sim 20 \mathrm{~km}$ west of the Liquiñe-Ofqui Fault Zone, but is not located directly upon any major regional structures. During April 2015, a sub-Plinian eruption occurred, with a bulk erupted volume of $\sim 0.3-0.6 \mathrm{~km}^{3}\left(\sim 0.1-0.2 \mathrm{~km}^{3}\right.$ DRE). The eruption was a rapid-onset event that produced highly crystalline products (from 40 to 60 vol.\%) including the mineral phases: plagioclase, clinopyroxene, orthopyroxene, amphibole, olivine, apatite, ilmenite, titanomagnetite and chalcopyrite. An upper-crustal reservoir is inferred using available geophysical data combined with amphibole geobarometry. Consideration of textural features, including high crystallinity, complex mineral zonation, crystal clots and interstitial glass between crystals from clots, suggests the presence of a mush zone within this reservoir. From the nine collected samples, whole-rock chemistry and an array of geothermometers (amphibole, amphibole-plagioclase, two-pyroxenes and $\mathrm{Fe}-\mathrm{Ti}$ oxides) gave similar results for all samples possessing $\sim 40$ vol.\% of crystals, with the exception of the sample Cal-160 ( $\sim 60$ vol.\% crystallinity), which is slightly more evolved and yields lower temperatures for all geothermometers. By comparing temperatures calculated in sample Cal-160 using pairs of ilmenite-titanomagnetite core compositions with those calculated using rim compositions, we observe a late-stage temperature increase of between 70 and $200^{\circ} \mathrm{C}$. We suggest that this local-scale heating event was at least partly responsible for triggering the eruption. Our data suggest that the bulk of the erupted magma was derived from a relatively uniform (970$1000{ }^{\circ} \mathrm{C}$ ), crystal-rich magma mass. Sample Cal-160 was derived from a cooler environment $\left(910-970{ }^{\circ} \mathrm{C}\right)$, where it was subjected to pre-eruptive heating to temperatures considerably higher than those observed in associated, erupted magmas (up to $1070{ }^{\circ} \mathrm{C}$ ). This requires the involvement of a hot, presumably mafic magma injection at the base of a shallow, crystal-rich reservoir, though the mafic magma was not itself erupted. The localised nature of interaction and rapidity of eruption onset have implications for potential future hazards at Calbuco volcano.
\end{abstract}

Keywords Calbuco volcano $\cdot$ Magma heating $\cdot$ Geothermobarometry $\cdot$ Crystal mush

Editorial responsibility: L. Pioli

Electronic supplementary material The online version of this article (https://doi.org/10.1007/s00445-019-1280-2) contains supplementary material, which is available to authorized users.

Eduardo Morgado

eeeem@leeds.ac.uk

1 Institute of Geophysics and Tectonics, School of Earth and Environment, University of Leeds, Leeds LS2 9JT, UK

2 Centro de Excelencia en Geotermia de los Andes (CEGA-FONDAP 15090013), Santiago, Chile
3 Departamento de Geología, Facultad de Ciencias Físicas y Matemáticas, Universidad de Chile, Santiago, Chile

4 Volcanic Risk Solutions, Institute of Agriculture and Environment, Massey University, Palmerston North 4442, New Zealand

5 GeoExpedition, Las Barrancas 25, Pirque, 9480000 Santiago, Chile

6 Environment, Earth and Ecosystems, The Open University, Milton Keynes MK7 6AA, UK 


\section{Introduction}

Within the continental crust, magma reservoirs are considered to be represented by both magma chambers, these being defined as continuous, melt-rich, lenticular regions where the magma is fluid and eruptible and within which magma crystallinity is $<45$ vol.\%, and crystal mushes, i.e. a body with a rigid crystal framework and crystallinity $>45 \%$ (Marsh 1989, 1996; Hildreth 2004; Bachmann and Bergantz 2008). Crystallinities $>45$ vol. $\%$ are associated with rheological properties which impede convection processes (e.g. Bachmann and Bergantz 2004, 2008; Huber et al. 2010a; Burgisser and Bergantz 2011; Parmigiani et al. 2014). These reservoirs exist as shallow magma reservoirs $(\leq 10 \mathrm{~km}$ depth) and may evolve over long cooling periods to become plutons (e.g. Koyaguchi and Kaneko 1999; Claiborne et al. 2010; Cooper and Kent 2014; Molina et al. 2015; Szymanowski et al. 2017; Cooper et al. 2017).

Sample mineralogy and whole-rock chemistry are usually studied together in order to understand magma reservoirs. Mineral compositions, however, yield diverse information regarding crystallisation conditions, crystal re-equilibration and timescales, which depend upon the diffusion kinetics of their constituent elements. For example, major elements of $\mathrm{Fe}-\mathrm{Ti}$ oxides show much higher interdiffusivity (Aragon et al. 1984; Aggarwal and Dieckmann 2002a, b) than those of silicate phases (e.g. plagioclase, Grove et al. 1984; clinopyroxene, Müller et al. 2013; orthopyroxene, Ganguly and Tazzoli 1994, Dohmen et al. 2016; and olivine, Dohmen and Chakraborty 2007a, b). Therefore, Fe-Ti oxides equilibrate much faster than silicate phases, typically recording magma eruption temperatures. By contrast, the silicates can provide information on earlier stages of the magmatic history with little re-equilibration. This study reports whole-rock chemistry, mineral chemistry, textural features and calculations of pre-eruptive intensive conditions (geothermometry, geobarometry and oxybarometry) derived from fall deposits of the sub-Plinian eruption of Calbuco volcano (Southern Chile), which occurred on 22-23 April 2015. In doing so, we recognise and quantify a local-scale heating event prior to the eruption, which we interpret to represent an input of new, hot magma beneath an inferred shallow magma reservoir including a mush zone with limited mixing or interaction between the overlying reservoir and the new magma input.

\section{Geological setting}

\section{Calbuco volcano}

Calbuco volcano $\left(41^{\circ} 19^{\prime} \mathrm{S}, 72^{\circ} 36^{\prime} \mathrm{W}\right)$ is a Late PleistoceneHolocene composite stratovolcano (López-Escobar et al. 1992) of the Central Southern Volcanic Zone of the Andes.
Its summit is $2003 \mathrm{~m}$ above sea level and the basal area of the volcano is $150 \mathrm{~km}^{2}$ (Sellés and Moreno 2011). Calbuco has been catalogued as the third most dangerous Chilean volcanic system (Lara et al. 2011; SERNAGEOMIN 2017). It is located $\sim 20 \mathrm{~km}$ west of the Liquiñe-Ofqui Fault Zone (LOFZ; Fig. 1), a major dextral, transpressive strike-slip structure of the Southern Volcanic Zone (Cembrano et al. 1996, 2000). According to Sellés and Moreno (2011), however, Calbuco volcano is not itself located directly upon any major regional structure. The basement of the area is composed of late Palaeozoic metamorphic rocks from the SotomóChaiquenes (Thiele et al. 1985) and Lenga (SERNAGEOMIN - BRGM 1995) metamorphic complexes and later plutonic rocks, which are members of the Miocene plutonic belt of the Northern Patagonian Batholith (LópezEscobar et al. 1992; Adriasola et al. 2006). The Calbuco volcanic edifice immediately overlies Early Pleistocene volcanic sequences (the Hueñuhueñu and Reloncaví strata; LópezEscobar et al. 1995b).

The construction of the Calbuco edifice is $\sim 300 \mathrm{ka}$ old (Sellés and Moreno 2011) and is characterised by alternations between lava flows (basaltic to basaltic andesitic with rare dacite), andesitic to dacitic domes and layers of pyroclastic tephras, block and ash flows, and deposits from hot and cold lahars (López-Escobar et al. 1992, 1995a, b; Petit-Breuilh 1999; Moreno et al. 2006; Stern et al. 2007; Castruccio et al. 2010; Sellés and Moreno 2011; Watt et al. 2011; Daga et al. 2014). The dominantly andesitic composition of its products (with high Sr isotope ratios and low Nd isotope ratios; LópezEscobar et al. 1995b), combined with the presence of crustal xenoliths and magmatic amphibole phenocrysts, make this volcano notably more evolved by comparison to other nearby volcanic complexes such as Osorno volcano (Parada 1990; López-Escobar et al. 1992, 1995a, b; Hickey-Vargas et al. 1995). The long-term evolution of the products of Calbuco volcano has been divided into four units (Lahsen et al. 1985; López-Escobar et al. 1992, 1995b; Sellés and Moreno 2011); details of the three prehistoric units (Calbuco 1, 2 and 3) are shown in Table 1 and details of the historical unit (Calbuco 4) are shown in Table 2.

\section{The April 2015 Calbuco eruption}

During 22-23 April 2015, two sub-Plinian eruptive events occurred at Calbuco volcano. The first eruptive pulse started on 22 April at 17:50 local time (20:50 UTC) and the second started on 23 April at 01:00 local time (04:00 UTC) (SERNAGEOMIN 2015a, b, c, d). These pulses produced eruptive columns with heights exceeding $15 \mathrm{~km}$ (SERNAGEOMIN 2015e; Romero et al. 2016; Van Eaton et al. 2016). Van Eaton et al. (2016) reported pyroclastic density currents (PDCs) at the end of the first eruptive pulse, with the largest PDCs occurring at the onset of the second eruptive 


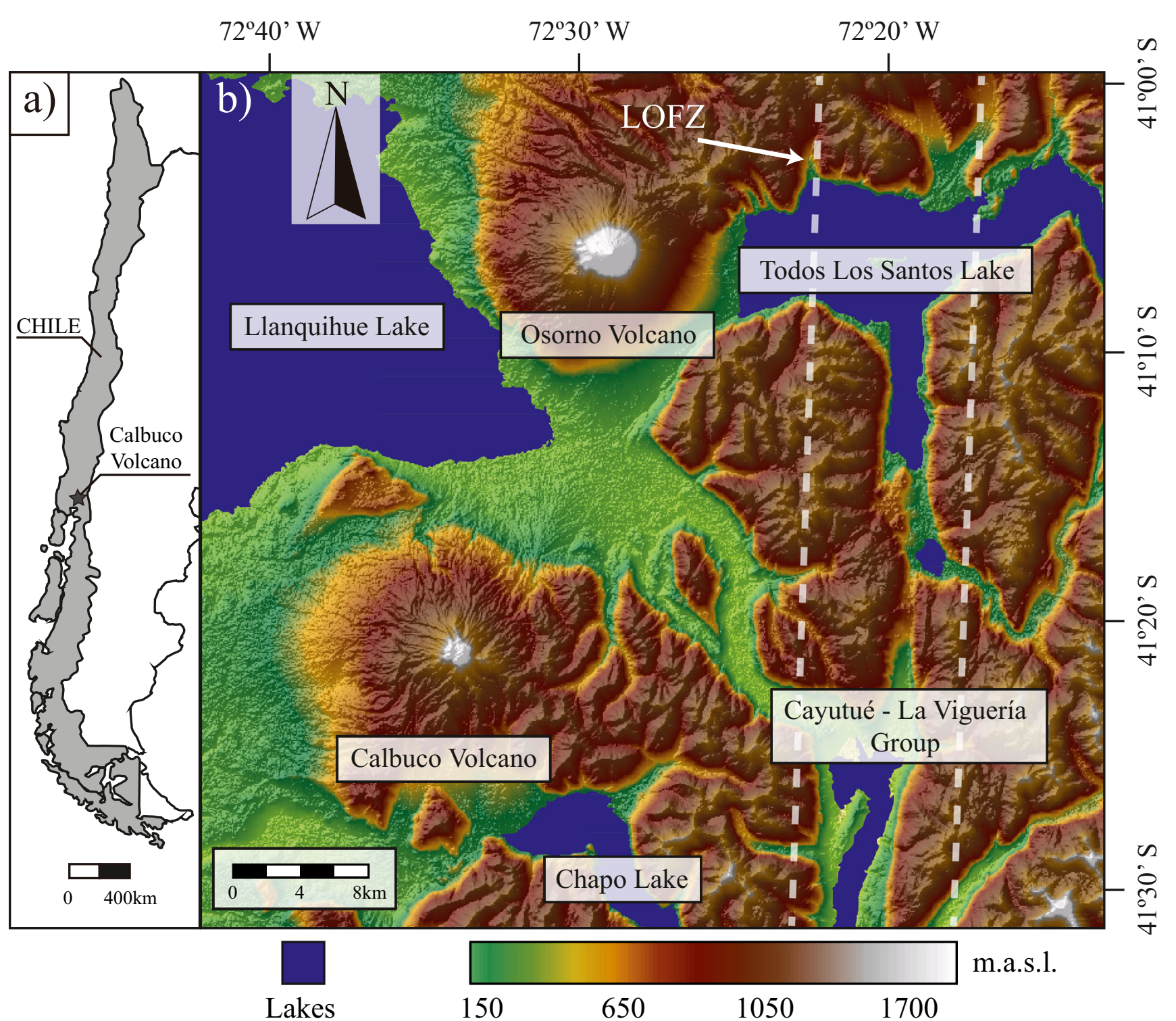

Fig. 1 (a) Location of Calbuco volcano with respect to Chile and (b) regional map of Calbuco volcano on shaded relief/Digital Elevation Model. Calbuco is located between Llanquihue and Chapo lakes, $20 \mathrm{~km}$ west from the Liquiñe-Ofqui Fault Zone (LOFZ, dashed white line). The Advanced Spaceborne Thermal Emission and Reflection Radiometer (ASTER) Global Digital Elevation Model (GDEM) image was obtained via EarthExplorer, USGS (http://earthexplorer.usgs.gov)

In terms of precursory activity, Valderrama et al. (2015) reported 147 seismic events occurring from 1 January to 21 April 2015, of which 142 were volcano-tectonic (VT, related to fracturing of the wall rock) and 5 were long-period (LP, related to collapse of gas bubbles in rising magma or fluid movement events). From February 2015, there was an increase in low-magnitude VT seismic activity and later, during 22 April, a seismic swarm of 140 VT events was recognised starting just $3 \mathrm{~h}$ before the eruption onset (SERNAGEOMIN 2015f). The first LP events were registered at 16:34 local time (19:34 UTC, $\sim 1.5 \mathrm{~h}$ before the eruption) and during the second pulse there was an increase in the number of VT seismic events (SERNAGEOMIN 2015g). Although no

during the first pulse (Romero et al. 2016). 
Table 1 Main features of the different prehistorical units of Calbuco volcano

\begin{tabular}{|c|c|c|}
\hline Unit & Description & Mineralogy ${ }^{b}$ \\
\hline $\begin{array}{l}\text { Calbuco } 1 \\
\quad(340-110 \\
\text { ka) }\end{array}$ & $\begin{array}{l}\text { Unit composed mainly of } \\
\text { andesite-basalt and scarce } \\
\text { basalt lavas } \\
\left(50-56.6 \mathrm{wt} . \% \mathrm{SiO}_{2}\right) \text { in- } \\
\text { terbedded with } \\
\text { volcanoclastic deposits. } \\
\text { The deposits lie in discon- } \\
\text { formity over plutonic and } \\
\text { metamorphic basement as } \\
\text { well as volcanic and } \\
\text { volcaniclastic deposits } \\
\text { (Estratos de Hueñuhueñu, } \\
1.4 \text { Ma; Lahsen 1985). } \\
\text { Sellés and Moreno (2011) } \\
\text { have recognised gabbro } \\
\text { and pyroxenite xenoliths }\end{array}$ & $\begin{array}{l}\text { Plagioclase, } \\
\text { clinopyroxene, } \\
\text { orthopyroxene, } \\
\text { olivine }^{\mathrm{a}} \text {, amphibole }\end{array}$ \\
\hline $\begin{array}{l}\text { Calbuco } 2 \\
\quad(110-14.5 \\
\text { ka) }\end{array}$ & $\begin{array}{l}\text { Unit composed mainly of } \\
\text { andesitic lavas } \\
\left(56-61 \mathrm{wt} \% \mathrm{SiO}_{2}\right) \\
\text { interbedded with } \\
\text { pyroclastic flows, fall } \\
\text { deposits and laharic } \\
\text { breccias. Occasionally can } \\
\text { be found andesitic dome } \\
\text { lavas, pyroclastic deposits } \\
\text { and volcanic avalanches } \\
\text { (Sellés and Moreno 2011) }\end{array}$ & $\begin{array}{l}\text { Plagioclase, } \\
\text { clinopyroxene, } \\
\text { orthopyroxene, } \\
\text { olivine }^{\mathrm{a}}\end{array}$ \\
\hline $\begin{array}{l}\text { Calbuco } 3 \\
\qquad(\sim 14 \text { ka to } \\
1893 \mathrm{AD})\end{array}$ & $\begin{array}{l}\text { Unit composed of lavas } \\
\text { (mainly of andesitic } \\
\text { composition), pyroclastic } \\
\text { rocks and laharic breccias. } \\
\text { Most of the samples have } \\
\text { andesite-basaltic and an- } \\
\text { desitic composition } \\
\left(55-60 \text { wt. } \% \mathrm{SiO}_{2}\right) \text {. } \\
\mathrm{Scarce} \text { dacites }(64.5 \text { wt.\% } \\
\mathrm{SiO}_{2} \text { ) also have been } \\
\text { recognised (Sellés and } \\
\text { Moreno 2011) }\end{array}$ & $\begin{array}{l}\text { Plagioclase, } \\
\text { clinopyroxene, } \\
\text { orthopyroxene, } \\
\text { olivine }^{\mathrm{a}}\end{array}$ \\
\hline
\end{tabular}

${ }^{a}$ All the olivines were surrounded by a pyroxene crown

${ }^{\mathrm{b}}$ According to Sellés and Moreno (2011)

deformation was recognised up to 1.5 days before the eruption, deflation was documented during the eruption (Delgado et al. 2017), which agrees with the contemporary tiltmeter information (Valderrama et al. 2015). According to Delgado et al. (2017) the deformation source models are consistent with a deflation between 8 and $11 \mathrm{~km}$ depth. The consequences of the eruption were not only local, where chemical-climate interaction modelling suggests that the 2015 Calbuco eruption led to an increase in the areal extent of the Southern ozone hole by $4.5 \times 10^{6} \mathrm{~km}^{2}$ (Ivy et al. 2017). Although on 30 April there was another eruptive pulse, this was a steam-
Table 2 Main features of the historical products of Calbuco volcano

Year of Description Mineralogy
the

the

eruption

1893

A violent eruption started on

February 1893 and finished

during the last months of 1895

(Petit-Breuilh 1999). During

October 1893 was the

paroxysmal stage, when the

eruptive column reached $\sim 9 \mathrm{~km}$

height (VEI 3 estimated; Fischer

1893; Petit-Breuilh 1999)

1911 During 1911 and 1912, gas and

ashes were erupted (Petit-Breuilh 1999)

1917 During April 1971, an eruption occurred with a lava flow, dome-cone and some lahars were associated. The lava flow had andesitic composition (59.3 wt.\% $\mathrm{SiO}_{2}$ ) and gabbroic and troctolitic clots were found (Sellés and Moreno 2011)

1929 During January 1929, 2.5-km-long (from the crater to NE direction) and $0.5-\mathrm{km}$-long (from the crater

Plagioclase, pyroxenes, olivine $^{\mathrm{a}}$, amphiboles to SE direction) andesitic lavas (55.5 wt.\% $\mathrm{SiO}_{2}$ ). Some crystal mush xenolith of amphibole gabbros have been recognised (Sellés and Moreno 2011).

Lahars were generated during the eruption flowing towards northwest (Petit-Breuilh 1999)

1961 During February 1961,

4.6-km-long (NE direction) and 1.7-km-long (SE direction) andesitic lavas were erupted. As a consequence, some lahars and hot lahars were generated (Klohn 1963; Moreno et al. 2006; Castruccio et al. 2010). According to the morphological features of glassy particles, this eruption is associated to magma/water interactions (Daga et al. 2014). Also granulitic, gabbroic and noritic clots have been recognised (Hickey-Vargas et al. 1995; Moreno and Sellés 2011)

*All the olivines were surrounded by a pyroxene crown

- No information available

driven eruption with little participation of fresh magma. The plume reached $<5 \mathrm{~km}$ above the vent with dispersion 
towards the SE (SERNAGEOMIN 2015g; Van Eaton et al. 2016). The registered deformation during this eruptive event was negligible (Delgado et al. 2017).

\section{Analytical procedures}

\section{Geochemistry}

Nine samples (four lapilli-sized pyroclasts from fall deposits and five bombs from pyroclastic density current deposits) were collected from the products of the 2015 Calbuco eruption deposits from seven locations (Fig. 2). Whole-rock compositions of three lapilli and four bomb samples were analysed via XRF (for major elements) at Acme Analytical Labs (Vancouver, Canada) using OREAS-184 and SY-4 standards for all the major elements, and CCU-1D and OREAS-700 standards for FeO. Accuracy for major elements in all standards is better than $3 \%$ (relative) except for $\mathrm{TiO}_{2}$ in $\mathrm{SY}-4$ which is $4.5 \%$ (relative) and $\mathrm{P}_{2} \mathrm{O}_{5}$ in OREAS-184 and SY-4 which are $14 \%$ and $17 \%$ (relative), respectively. Trace element compositions were analysed via ICP-MS at the Open University (Milton Keynes, UK) using the BHVO-2, JB-2 and AGV-1 standards. The reproducibility of analyses was better than $8 \%$ (relative; $2 \sigma$ ) and accuracy in the trace elements in JB-2 $(n=5)$, BHVO-2 $(n=2)$ and AGV-1 $(n=2)$ is better than $10 \%$, except in $\mathrm{Ni}(21 \%$ in AGV- 1$)$ and $\mathrm{Pb}$ (13\% in BHVO-2).

The mineral chemistry analyses of amphibole, plagioclase, pyroxene, $\mathrm{Fe}-\mathrm{Ti}$ oxide and olivine were measured using an electron microprobe (JEOL JXA8230) at Leeds Electron Microscopy and Spectroscopy Centre at the University of Leeds (Leeds, UK). Counting time is distributed equally between on-peak and background measurements, using the following conditions:

Amphiboles Major and minor element concentrations ( $\mathrm{Si}$, Ti, $\mathrm{Al}, \mathrm{Fe}, \mathrm{Mn}, \mathrm{Mg}, \mathrm{Ca}, \mathrm{Na}, \mathrm{K}, \mathrm{Cr}, \mathrm{Cl}$ and $\mathrm{F}$ ) were measured in the cores of amphibole grains. The analytical conditions consisted of an accelerating potential of $20 \mathrm{keV}$ and focused beam for all the elements. An electron beam current of $15 \mathrm{nA}$ was used for $\mathrm{Si}$, Ti, $\mathrm{Al}, \mathrm{Fe}, \mathrm{Mn}, \mathrm{Mg}, \mathrm{Ca}, \mathrm{Na}, \mathrm{K}$ and $\mathrm{Cr}$, whereas a current of $100 \mathrm{nA}$ was used for $\mathrm{F}$ and $\mathrm{Cl}$. Counting times were $30 \mathrm{~s}$ for
Fig. 2 Location of samples (lapilli and bombs) from the 2015 Calbuco eruption on shaded relief/Digital Elevation Model. Location of pyroclastic density currents (white) and lahars (blue) are based on Castruccio et al. (2016). The ASTER-GDEM Image obtained via EarthExplorer, USGS (http:// earthexplorer.usgs.gov)

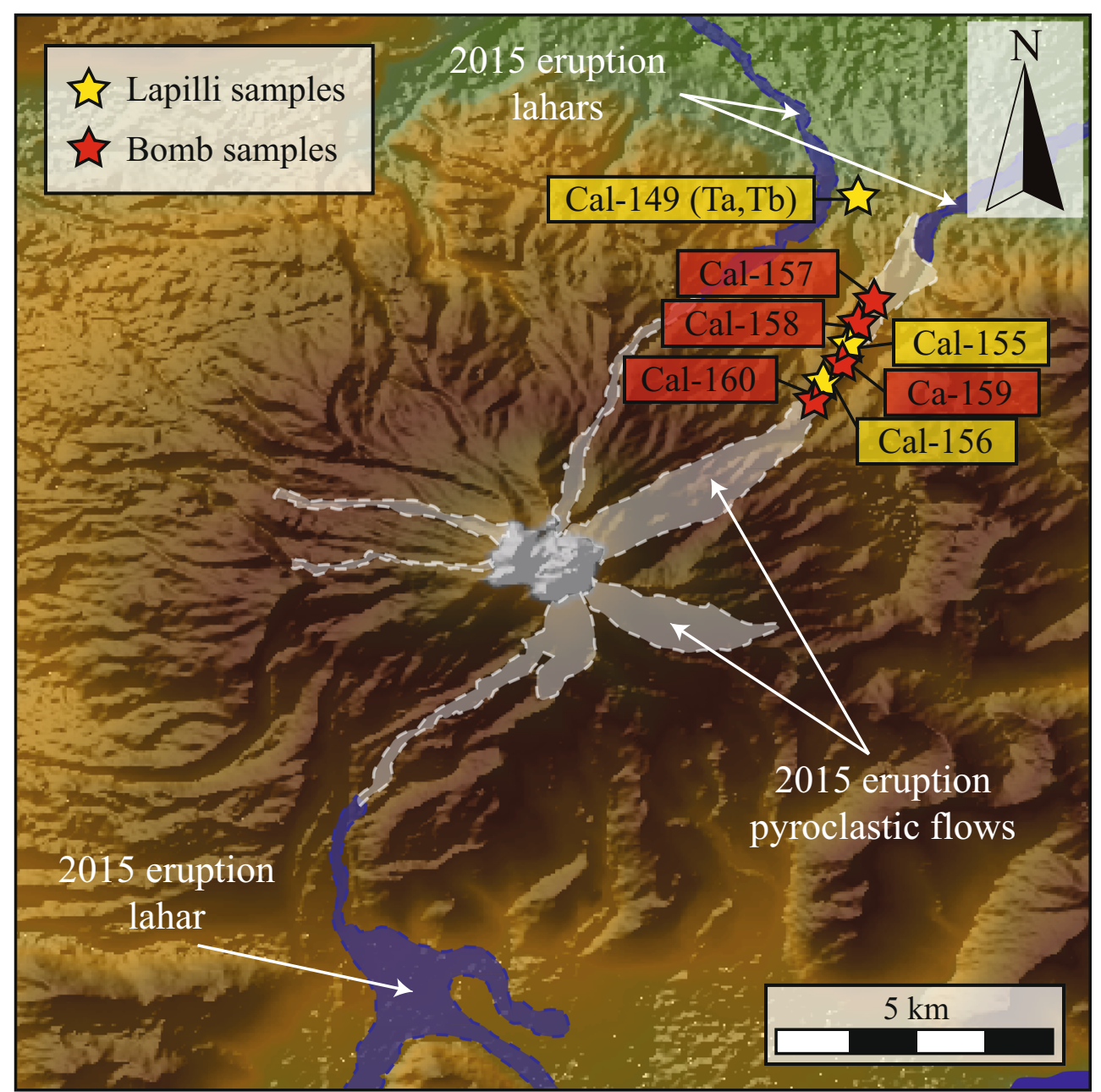


Ti, Al, Cr, Fe, Mn, Mg, Ca and $\mathrm{Na}$; $40 \mathrm{~s}$ for $\mathrm{Si}, 100 \mathrm{~s}$ for $\mathrm{F}$ and $80 \mathrm{~s}$ for $\mathrm{Cl}$. Values of $\mathrm{Fe}^{3+}$ were obtained following the formulation of Leake et al. (1997).

Plagioclases Compositional profiles (spacing $\sim 4-8 \mu \mathrm{m}$ ) of major ( $\mathrm{Si}, \mathrm{Al}, \mathrm{Ca}, \mathrm{Na}$ and $\mathrm{K}$ ) and minor (Ti, Fe, $\mathrm{Mg}, \mathrm{Sr}$ and $\mathrm{Ba}$ ) element concentrations were obtained in plagioclase phenocrysts. The analytical conditions consisted of an accelerating potential of $20 \mathrm{keV}$ and electron beam current of $10 \mathrm{nA}$ for major elements and $40 \mathrm{nA}$ for minor elements with a defocused beam ( 2 to $5 \mu \mathrm{m}$ ) in order to reduce volatile alkali loss. Counting times for major elements were $32 \mathrm{~s}, 240 \mathrm{~s}$ for $\mathrm{Ti}, \mathrm{Fe}$ and $\mathrm{Ba}$, and $480 \mathrm{~s}$ for $\mathrm{Mg}$ and $\mathrm{Sr}$.

Clinopyroxenes and orthopyroxenes Concentrations of major ( $\mathrm{Si}, \mathrm{Mg}, \mathrm{Fe}$ and $\mathrm{Ca}$ ), minor and trace (Ti, Al, Mn, $\mathrm{Cr}, \mathrm{Ni}$ ) elements were obtained in pyroxene phenocryst cores and rims. The analytical conditions consisted of an accelerating potential of $20 \mathrm{keV}$ and electron beam current of $30 \mathrm{nA}$ with a focused beam. Counting times for major elements were $60 \mathrm{~s}$ and $80 \mathrm{~s}$ for minor and trace elements. Values of $\mathrm{Fe}^{3+}$ were obtained following the formulation of Putirka (2008).

Fe-Ti oxides Compositional profiles (spacing $\sim 2-3 \mu \mathrm{m}$ ) of major ( $\mathrm{Ti}, \mathrm{Fe}$ and $\mathrm{O}$ ) and minor and trace (Al, $\mathrm{Mg}, \mathrm{Ca}, \mathrm{Mn}$, $\mathrm{V}, \mathrm{Cr}, \mathrm{Zn}, \mathrm{Ni}, \mathrm{Co}$ and $\mathrm{Si}$ ) elements were measured in titanomagnetite and ilmenite. The analytical conditions consisted of an accelerating potential of $15 \mathrm{keV}$ and electron beam current of $30 \mathrm{nA}$ with a focused beam. Counting times for all the elements were $60 \mathrm{~s}$ except for $\mathrm{O}$, in which counting times were $260 \mathrm{~s}$. Values of $\mathrm{Fe}^{3+}$ were obtained following the formulations of Droop (1987) for ilmenite grains and Stormer (1983) for titanomagnetites.

Olivines Concentrations of major ( $\mathrm{Si}, \mathrm{Mg}$ and $\mathrm{Fe}$ ), minor and trace (Al, Ni, Mn, Ca) elements were obtained in the core of olivine phenocryst. Analyses were taken away from grain boundaries in order to avoid secondary fluorescence issues during the acquisition of $\mathrm{Ca}$ concentrations (cf. Dalton and Lane 1996). The analytical conditions consisted of an accelerating potential of $20 \mathrm{keV}$ and electron beam current of $30 \mathrm{nA}$ for $\mathrm{Si}, \mathrm{Fe}, \mathrm{Mg}$ and $\mathrm{Mn}$ and $100 \mathrm{nA}$ for $\mathrm{Al}, \mathrm{Ni}$ and $\mathrm{Ca}$, all with a focused beam. Counting times for all the elements but $\mathrm{Ca}$ were $40 \mathrm{~s}$ and $400 \mathrm{~s}$ for $\mathrm{Ca}$.

\section{Geothermobarometry}

Amphiboles The methods of Ridolfi et al. (2010) and Ridolfi and Renzulli (2012) are used to calculate intensive conditions ( $\mathrm{T}, \mathrm{P}$ and $\mathrm{fO}_{2}$ ) ) independently in 109 amphibole cores from both Cal-149Ta (light-brown lapilli) and Cal-160 (white bomb) samples.
Amphibole-plagioclases The Holland and Blundy (1994) thermometry is applied using core compositions of 16 plagioclase-amphibole pairs, where equilibrium is assumed because the plagioclase crystals are found as inclusions in amphibole phenocrysts.

Clinopyroxene-orthopyroxenes Two-pyroxene thermobarometry (Putirka 2008) is used with 35 ortho- and clinopyroxene pairs that passed the test for equilibrium according to the Putirka (2008) chemical filter across the nine samples.

Fe-Ti oxides The Ghiorso and Evans (2008) thermoxybarometer is applied to compositions of crystal cores and close $(\sim 2 \mu \mathrm{m}$ to the interface) to ilmenite-titanomagnetite grain boundaries.

Olivine The Ca-in-olivine thermometer of Shejwalkar and Coogan (2013) is applied to core composition data from 16 olivine phenocrysts in crystal clots, where equilibrium with the surrounding crystal phases (plagioclase, clinopyroxene and orthopyroxene) is assumed due to textural relation and chemical filters (cf. Grove et al. 1997). Nine calculated temperatures were discarded, due to the low forsterite content $\left(\mathrm{Fo}_{61-68}\right)$ of the crystals considering $\mathrm{Fo}_{70}$ as the lower limit of the calibration of the thermometer (Shejwalkar and Coogan 2013).

The error propagation of geothermo- and geobarometers is carried out considering both internal uncertainties (associated with the experimental method) and external uncertainties (associated with precision and accuracy electron microprobe analyses). In later parts of this work, MELTS modelling uses the intensive physical variables derived from the thermobarometry (see 'Intensive variable conditions' section).

\section{Descriptions and compositions of the samples}

According to Castruccio et al. (2016) the fall deposits of the 22-23 April eruptions are made up of four sub-units: the lower layer (unit 0) corresponds to the first event and is composed mainly of light-brown, highly vesicular basaltic andesite scoria and up to 10 vol.\% of lithics. Layers 1, 2 and 3 correspond to the second (largest) event and there is a transition in the dominant clast type present in the deposits, from light-brown scoria in layer 1 to dark-brown, dense juveniles with the same composition within layer 3. Samples Cal-149Ta, Cal-155 and Cal-156 correspond to layer 1, the sample Cal-149Tb corresponds to layer 3, samples Cal-157, Cal-158 and Cal-159 correspond to scoriaceous bombs from PDCs, and sample Cal-160 corresponds to a distinctive, white bomb with darker zones extracted from a PDC deposit.

All samples are porphyric, with $\sim 35$ to 65 vol. $\%$ of phenocrysts. Dominant mineral phases present in all the samples are plagioclase, orthopyroxene and clinopyroxene. Minor phases include amphibole (only in 
Cal-149Ta and Cal-160), olivine (in all samples except Cal-160), titanomagnetite, ilmenite, apatite and chalcopyrite. All the mineral phases are present as clots of crystals and isolated crystals. The samples exhibit crystallinities of $\sim 40$ vol.\% except for Cal-160, which shows a higher crystallinity of $\sim 60$ vol.\% (Table 3 ). The samples show a large range of vesicularities: from 15 to 60 vol. $\%$ and the highest values correspond to light-brown lapilli (samples Cal-149Ta, Cal-155, Cal156) from 42 to 60 vol.\% (see details in Table 3). The crystallinity percentages and quantification of the main petrographic of the collected products of the April 2015 Calbuco eruption were obtained by image processing techniques via 'Background Extraction' of pseudo-coloured images through the freeware JMicrovision.

All the samples correspond to calc-alkaline basaltic-andesites (55.6-56.9 $\mathrm{SiO}_{2}$ wt.\%; Fig. 3a). The $\mathrm{Mg \#} \mathrm{(Mg \# =}$ molar $\left.\mathrm{Mg} /\left(\mathrm{Mg}+\mathrm{Fe}^{2+}\right)\right)$ values are from 0.56 to 0.59 . The maximum $\mathrm{SiO}_{2}$ content (56.9 wt.\%) and the minimum Mg\# (0.56) correspond to the Sample Cal-160 (Table 4; Fig. 3). All samples show similar rare earth elements (REE) patterns, with a narrow range of $\mathrm{La}_{\mathrm{N}} / \mathrm{Yb}_{\mathrm{N}}(2-$ 2.4); only the sample Cal-155 shows a slight positive $\mathrm{Eu}$ anomaly (see Online Resource 1). The spider diagram of the studied samples shows similar trends in all samples and display positive $\mathrm{Rb}, \mathrm{Pb}$ and $\mathrm{Sr}$ anomalies and negative $\mathrm{Nb}, \mathrm{P}$ and $\mathrm{Ti}$ anomalies, which are typical of magmas from arc settings (Fig. 3c).

\section{Mineral chemistry and petrography}

Plagioclase Plagioclase phenocrysts are $0.1-2.0 \mathrm{~mm}$ in size and can be found as isolated crystals and as members of cumulocrysts and glomerocrysts (together with pyroxene, olivine, titanomagnetite, apatite, amphibole and scarce sulphides). Most of the plagioclase phenocrysts display zonation patterns with distinct cores and rims, with the exception of some crystals found as inclusions in amphibole and pyroxene crystals.

Two compositional types were identified in plagioclase phenocrysts: zone 1 corresponds to compositions of $\mathrm{An}_{80-92}$ (Figs. 4 and 5), which is restricted to phenocryst cores. Zone 2 corresponds to compositions of $\mathrm{An}_{46-79}$ (Fig. 4), mainly located on phenocryst rims, where oscillatory zonation is ubiquitous (Fig. 6). According to the presence/absence of these zones, plagioclase crystals have been classified into two groups:

Group I: Crystal core shapes are euhedral to subhedral, resorption features and patchy zonation are not recognised. Core compositions correspond to zone 1 compositions. The rims have variable thickness (from 20 to $280 \mu \mathrm{m}$ ) and their compositions correspond to zone 2 compositions.

Group II: These plagioclase crystals show oscillatory zoning within zone 2 compositional range. Resorption and sieve texture as well as patchy zoning are very common.

Plagioclase grains found as inclusions in amphibole have compositions in the range $\mathrm{An}_{50-89}$.

Amphibole Amphibole phenocrysts are found only in Cal149Ta (fall deposit, layer 1) and Cal-160 (white bomb from PDC). All Cal-149Ta amphiboles of Cal-149Ta are pargasites (after Leake et al. 1997; $\mathrm{Mg} \#=0.64-0.74 ; \mathrm{Si}$ apfu $=6.3-6.5$; Fig. 7) and can be found as isolated crystals and glomerocrysts (together with plagioclase, pyroxene, titanomagnetite, olivine, ilmenite and apatite). All amphibole phenocrysts are euhedral and usually contain plagioclase inclusions. In sample Cal-160, 70\% of the amphiboles are edenite $\left(\mathrm{NaCa}_{2} \mathrm{Mg}_{5}\left(\mathrm{AlSi}_{7}\right) \mathrm{O}_{22}(\mathrm{OH})_{2}\right)$ (after Leake et al. 1997; Mg\# = 0.65-0.77; Si apfu = 6.5-6.6; Fig. 8), and 30\% are pargasites $\left(\mathrm{NaCa}_{2}(\mathrm{Mg}, \mathrm{Fe})_{4} \mathrm{Al}_{(}\left(\mathrm{Al}_{2} \mathrm{Si}_{6}\right) \mathrm{O}_{22}(\mathrm{OH})_{2}\right)$ (after
Table 3 Main features of the samples analysed from Calbuco's April 2015 eruption

\begin{tabular}{llllllllll}
\hline Section name (Cal-) & $149 \mathrm{Ta}$ & $149 \mathrm{~Tb}$ & 155 & 156 & $157 \mathrm{a}$ & $157 \mathrm{~b}$ & 158 & 159 & 160 \\
\hline Description & LL & DL & LL & LL & DB & DB & DB & DB & WB \\
Vesicles (total \%) & 59.8 & 15.4 & 42.3 & 51.4 & 32.9 & 49.7 & 41.1 & 37.2 & 25.4 \\
Groundmass (total \%) & 22.3 & 52.9 & 38 & 31.5 & 37 & 28.9 & 35.8 & 39.6 & 27.1 \\
Plagioclases (total \%) & 12 & 23.1 & 14.7 & 12.9 & 18.1 & 14.2 & 16.1 & 15.7 & 35.2 \\
Pyroxenes (total \%) & 3.8 & 7.1 & 3.7 & 3.9 & 11.1 & 5.8 & 5.4 & 6.3 & 9.7 \\
Amphiboles (total \%) & 1.2 & - & - & - & - & - & - & $>0.1$ & $>0.1$ \\
Olivine (total \%) & - & 0.1 & 0.1 & $>0.1$ & 0.1 & $>0.1$ & 0.1 & $>0.1$ & - \\
Oxides (total\%) & 0.9 & 1.4 & 1.2 & 0.3 & 0.9 & 1.4 & 1.5 & 1.2 & 2.5 \\
Crystallinity (\%) & 44.5 & 37.5 & 34.1 & 35.2 & 44.9 & 42.5 & 39.2 & 36.9 & 63.7 \\
\hline
\end{tabular}

$L L$ light-brown lapilli, $D L$ dark lapilli, $D B$ dark bomb, $W B$ white bomb

${ }^{\text {a }}$ Percentage not considering vesicles 

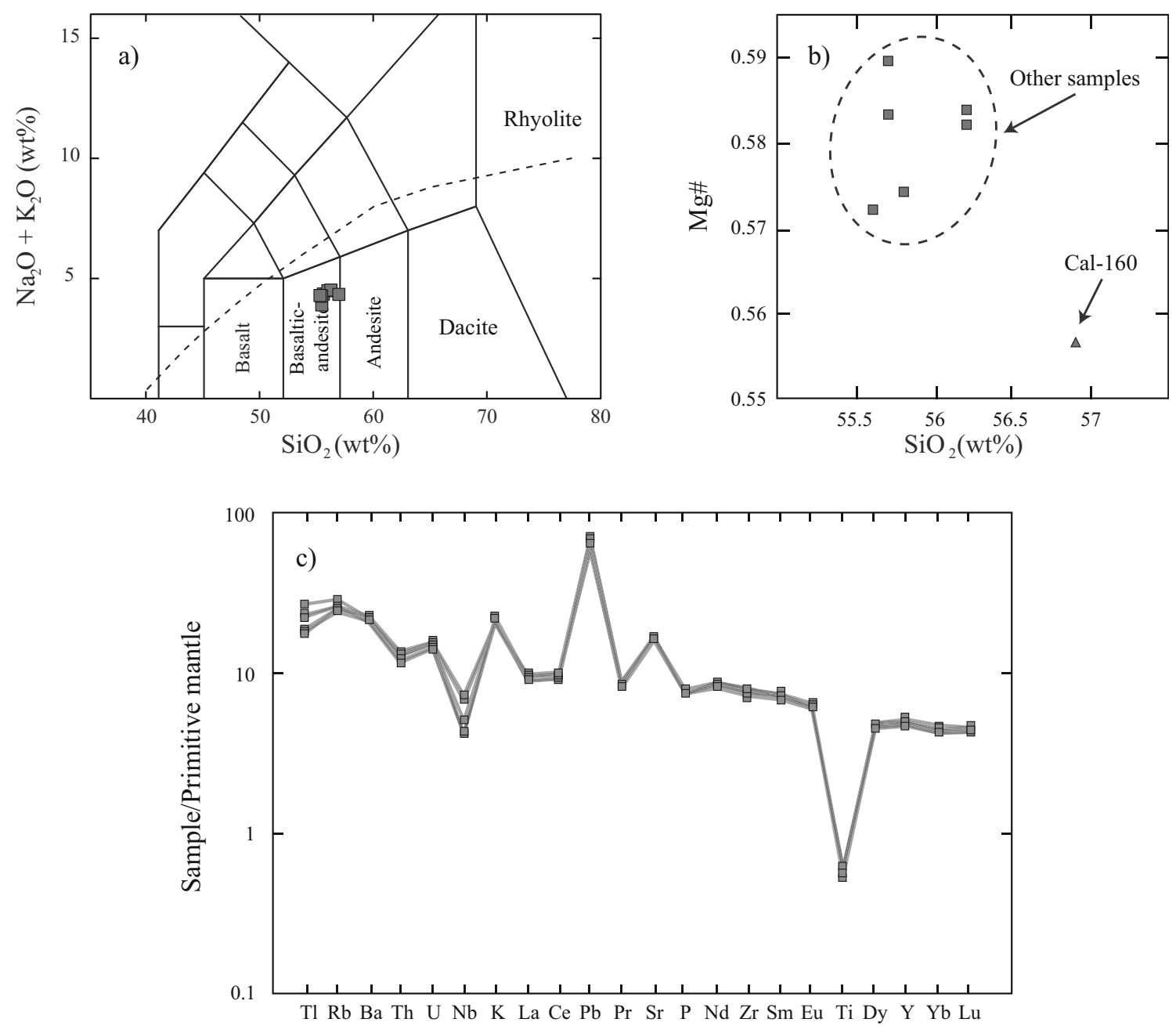

Fig. 3 (a) Total alkali versus silica (Le Bas et al. 1986) plots of the Calbuco 2015 volcanic products. Boundary dashed line between alkaline and subalkaline rocks is taken from Irvine and Baragar (1971). (b) Variation diagram of $\mathrm{SiO}_{2}$ (wt.\%) versus Mg\# (details in Table 4), where sample Cal-160 shows the highest $\mathrm{Mg \#}$ and the lowest $\mathrm{SiO}_{2}$ wt.\%. (c) Primitive mantle-normalised (Sun and McDonough 1989) spider diagram. Details of major and trace element concentrations are available in Table 4
Leake et al. 1997; Mg\# = 0.71-0.77; $\mathrm{Si}$ apfu $=6.2-6.5$ ). In contrast to Cal-149Ta, amphiboles in Cal-160 are anhedral and are found as members of glomerocrysts (together with plagioclase, pyroxene, titanomagnetite, olivine, ilmenite and apatite).

Fe-Ti oxides Ilmenite grains are scarce and have composition of $\mathrm{X}_{\mathrm{ilm}}$ (i.e. the cation atomic proportion of $\mathrm{Ti}$ ) $=0.77-0.85$ (i.e. $\mathrm{X}_{\mathrm{hmt}}$, the cationic proportion of $\mathrm{Fe}^{2+}=0.15-0.23$ ). They occur as both inclusions and in contact with titanomagnetites. Titanomagnetites can be classified into two groups: high-Ti, with a relatively high ulvöspinel component $\left(\mathrm{X}_{\mathrm{usp}}=0.42-\right.$ $\left.0.46 ; \mathrm{X}_{\mathrm{mgt}}=0.54-0.58\right)$ and low-Ti $\left(\mathrm{X}_{\mathrm{usp}}=0.10-0.17\right.$; $\left.\mathrm{X}_{\mathrm{mgt}}=0.83-0.9\right)$. They appear as isolated crystals or in clots of crystals together with amphibole, plagioclase, pyroxene, olivine, ilmenite and apatite.
Pyroxenes Pyroxenes are found both as isolated grains and as members of clots of crystals together with amphibole, plagioclase, pyroxene, olivine, ilmenite, titanomagnetite, apatite and chalcopyrite (see Online Resource 2). All the pyroxene crystals exhibit slight reverse and oscillatory zoning. Clinopyroxene crystals exhibit reverse zoning, from $\mathrm{En}_{43-47} \mathrm{Fe}_{9-15} \mathrm{Wo}_{40-44}$ (Fig. 8) composition in the cores to $\mathrm{En}_{44-46} \mathrm{Fe}_{10-12} \mathrm{Wo}_{43-45}$ composition in the rims (Figs. 8 and 9); oscillatory zoning with compositions of $\mathrm{En}_{43-46} \mathrm{Fe}_{10-13} \mathrm{Wo}_{42-45}$ (Figs. 8 and 9) have also been observed. Orthopyroxenes exhibit reverse zoning from $\mathrm{En}_{67}$ ${ }_{69} \mathrm{Fe}_{29-31} \mathrm{Wo}_{2-3}$ composition in the cores to $\mathrm{En}_{69-71} \mathrm{Fe}_{26}$ ${ }_{28} \mathrm{Wo}_{2-3}$ composition in the rims (Fig. 9); oscillatory zoning with compositions of $\mathrm{En}_{69-72} \mathrm{Fe}_{24-27} \mathrm{Wo}_{2-4}$ (Figs. 8 and 9) have also been recognised. 
Table 4 Whole-rock analyses of samples from the 2015 Calbuco eruption

\begin{tabular}{|c|c|c|c|c|c|c|c|c|}
\hline & Detection limit & $\begin{array}{l}\text { Cal- } \\
\text { 149A } \\
\text { Lapilli }\end{array}$ & $\begin{array}{l}\text { Cal- } \\
\text { 149B } \\
\text { Lapilli }\end{array}$ & $\begin{array}{l}\text { Cal- } \\
155 \\
\text { Lapilli }\end{array}$ & $\begin{array}{l}\text { Cal- } \\
157 \\
\text { Bomb }\end{array}$ & $\begin{array}{l}\text { Cal- } \\
158 \\
\text { Bomb }\end{array}$ & $\begin{array}{l}\text { Cal- } \\
159 \\
\text { Bomb }\end{array}$ & $\begin{array}{l}\text { Cal- } \\
160 \\
\text { Bomb }\end{array}$ \\
\hline $\mathrm{SiO}_{2}$ & $0.01(\%)$ & 56.2 & 56.2 & 55.6 & 55.7 & 55.8 & 55.7 & 56.9 \\
\hline $\mathrm{Al}_{2} \mathrm{O}_{3}$ & $0.01(\%)$ & 18.8 & 18.7 & 18.9 & 18.8 & 18.9 & 18.7 & 18.6 \\
\hline $\mathrm{TiO}_{2}$ & $0.01(\%)$ & 0.93 & 0.92 & 0.87 & 0.92 & 0.93 & 0.94 & 0.82 \\
\hline $\mathrm{FeO}$ & $0.2(\%)$ & 4.99 & 4.99 & 5.69 & 5.27 & 5.55 & 5.27 & 5.41 \\
\hline $\mathrm{Fe}_{2} \mathrm{O}_{3}$ & $0.01(\%)$ & 2.87 & 2.77 & 2.22 & 2.60 & 2.41 & 2.71 & 2.17 \\
\hline $\mathrm{MnO}$ & $0.01(\%)$ & 0.16 & 0.16 & 0.17 & 0.17 & 0.17 & 0.15 & 0.16 \\
\hline $\mathrm{MgO}$ & $0.01(\%)$ & 3.93 & 3.9 & 4.27 & 4.14 & 4.2 & 4.25 & 3.81 \\
\hline $\mathrm{CaO}$ & $0.01(\%)$ & 8.04 & 7.96 & 8.21 & 8.16 & 8.14 & 8.12 & 7.63 \\
\hline $\mathrm{Na}_{2} \mathrm{O}$ & $0.01(\%)$ & 3.77 & 3.78 & 3.45 & 3.65 & 3.65 & 3.65 & 3.67 \\
\hline $\mathrm{K}_{2} \mathrm{O}$ & $0.01(\%)$ & 0.62 & 0.64 & 0.53 & 0.61 & 0.61 & 0.61 & 0.67 \\
\hline $\mathrm{P}_{2} \mathrm{O}_{5}$ & $0.01(\%)$ & 0.17 & 0.16 & 0.15 & 0.16 & 0.16 & 0.16 & 0.16 \\
\hline LOI & & -0.3 & -0.3 & -0.2 & -0.3 & -0.3 & -0.3 & -0.1 \\
\hline Total & & 100.48 & 100.18 & 100.06 & 100.18 & 100.52 & 100.26 & 99.99 \\
\hline $\mathrm{Li}$ & $0.03(\mathrm{ppm})$ & 15.12 & 15.65 & 14.85 & 14.83 & 14.17 & 14.69 & 16.87 \\
\hline $\mathrm{Sc}$ & $0.05(\mathrm{ppm})$ & 21.75 & 22.82 & 21.43 & 23.23 & 22.76 & 24.04 & 19.91 \\
\hline V & 0.07 (ppm) & 181.7 & 183.7 & 185.3 & 189.3 & 188.6 & 197.1 & 170.1 \\
\hline $\mathrm{Co}$ & $0.01(\mathrm{ppm})$ & 40.90 & 38.86 & 43.27 & 38.36 & 38.29 & 34.86 & 34.81 \\
\hline $\mathrm{Ni}$ & $0.32(\mathrm{ppm})$ & 10.01 & 10.81 & 11.73 & 12.92 & 15.72 & 12.88 & 11.00 \\
\hline $\mathrm{Cu}$ & $0.66(\mathrm{ppm})$ & 44.19 & 45.37 & 24.05 & 50.56 & 47.50 & 45.99 & 36.92 \\
\hline $\mathrm{Cr}$ & 0.01 (ppm) & 12.90 & 14.92 & 15.08 & 18.19 & 17.41 & 16.98 & 15.84 \\
\hline $\mathrm{Zn}$ & 2.207 (ppm) & 79.84 & 75.96 & 79.41 & 76.31 & 78.27 & 81.24 & 81.82 \\
\hline $\mathrm{Tl}$ & 0.04 (ppm) & 0.115 & 0.111 & 0.117 & 0.094 & 0.091 & 0.088 & 0.135 \\
\hline $\mathrm{Rb}$ & $0.01(\mathrm{ppm})$ & 16.48 & 16.37 & 14.27 & 15.92 & 15.17 & 15.83 & 18.35 \\
\hline $\mathrm{Ba}$ & 0.5 (ppm) & 152.1 & 151.6 & 131.4 & 146.0 & 139.7 & 145.3 & 164.0 \\
\hline Th & 0.001 (ppm) & 1.10 & 1.03 & 0.88 & 1.02 & 0.97 & 1.01 & 1.20 \\
\hline $\mathrm{U}$ & 0.001 (ppm) & 0.310 & 0.310 & 0.259 & 0.304 & 0.287 & 0.296 & 0.350 \\
\hline $\mathrm{Nb}$ & $0.003(\mathrm{ppm})$ & 152.09 & 151.65 & 131.44 & 145.98 & 139.66 & 145.29 & 164.03 \\
\hline $\mathrm{La}$ & 0.001 (ppm) & 1.098 & 1.028 & 0.882 & 1.020 & 0.971 & 1.010 & 1.201 \\
\hline $\mathrm{Ce}$ & 0.002 (ppm) & 0.31 & 0.31 & 0.26 & 0.30 & 0.29 & 0.30 & 0.35 \\
\hline $\mathrm{Pb}$ & 0.14 (ppm) & 4.99 & 4.67 & 6.57 & 4.02 & 4.25 & 4.39 & 4.96 \\
\hline $\operatorname{Pr}$ & 0.005 (ppm) & 2.391 & 2.411 & 1.950 & 2.301 & 2.194 & 2.287 & 2.450 \\
\hline $\mathrm{Sr}$ & $0.02(\mathrm{ppm})$ & 347 & 355 & 375 & 350 & 335 & 352 & 353 \\
\hline $\mathrm{Nd}$ & 0.001 (ppm) & 11.79 & 11.82 & 9.44 & 11.35 & 10.80 & 11.27 & 11.81 \\
\hline $\mathrm{Zr}$ & 0.06 (ppm) & 88.50 & 87.26 & 68.32 & 83.80 & 79.55 & 83.97 & 89.78 \\
\hline $\mathrm{Sm}$ & 0.001 (ppm) & 3.271 & 3.259 & 2.478 & 3.143 & 3.012 & 3.155 & 3.111 \\
\hline $\mathrm{Eu}$ & 0.001 (ppm) & 1.030 & 1.083 & 0.957 & 1.019 & 0.993 & 1.003 & 1.026 \\
\hline $\mathrm{Gd}$ & 0.001 (ppm) & 3.520 & 3.453 & 2.626 & 3.355 & 3.225 & 3.369 & 3.278 \\
\hline $\mathrm{Tb}$ & $0.001(\mathrm{ppm})$ & 0.583 & 0.584 & 0.436 & 0.562 & 0.546 & 0.571 & 0.546 \\
\hline Dy & 0.001 (ppm) & 3.576 & 3.577 & 2.648 & 3.439 & 3.308 & 3.452 & 3.338 \\
\hline Ho & 0.001 (ppm) & 0.784 & 0.776 & 0.581 & 0.752 & 0.723 & 0.756 & 0.726 \\
\hline $\mathrm{Er}$ & 0.01 (ppm) & 2.221 & 2.204 & 1.651 & 2.121 & 2.047 & 2.131 & 2.062 \\
\hline $\mathrm{Y}$ & 0.01 (ppm) & 22.48 & 23.16 & 17.13 & 22.06 & 20.90 & 22.18 & 21.27 \\
\hline $\mathrm{Yb}$ & 0.01 (ppm) & 2.187 & 2.300 & 1.719 & 2.171 & 2.056 & 2.114 & 2.047 \\
\hline $\mathrm{Lu}$ & $0.002(\mathrm{ppm})$ & 0.333 & 0.335 & 0.254 & 0.322 & 0.311 & 0.326 & 0.316 \\
\hline
\end{tabular}

Olivine Olivine grains are found surrounded by pyroxene and titanomagnetite crystals (see example images on Online Resource 2). Their composition of $\mathrm{Fo}_{60-75}$ (Fig. 8) is fairly homogeneous for each crystal, thus no zonation patterns are recognised. Olivine crystals were found in all the samples except Cal-160 (Table 3).

\section{Intensive variable conditions}

\section{Two-pyroxene thermobarometry}

Mineral pairs measured in all samples except Cal-160 give temperatures of $958-1013 \pm 56{ }^{\circ} \mathrm{C}$ (Fig. 10; Table 5), with 


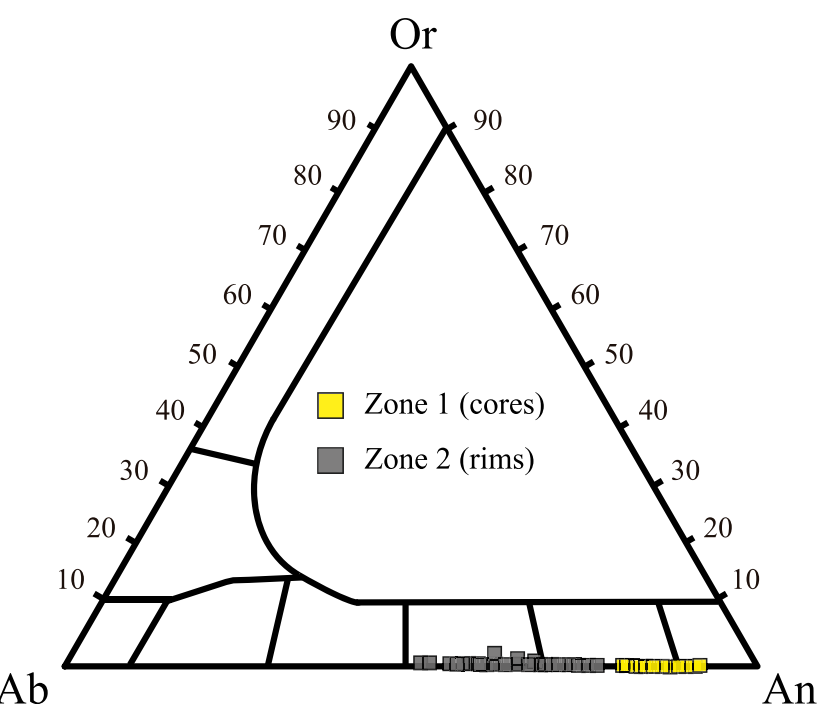

Figure. 4 Plagioclase compositions of the studied samples. Zone 1 represents core compositions of group I, whereas zone 2 represents rim compositions of group I and the whole-crystal composition of group II an average of $984^{\circ} \mathrm{C}\left(\sigma=12{ }^{\circ} \mathrm{C}\right)$, and pressures of $1.5-4.7 \pm$ $3.2 \mathrm{kbar}$ (Table 5), with an average of $3.3 \mathrm{kbar}(\sigma=0.8 \mathrm{kbar}$ ). The pairs measured in the sample Cal-160 give temperatures of 944-981 $\pm 56{ }^{\circ} \mathrm{C}$ (Fig. 10; Table 6), with an average of $968{ }^{\circ} \mathrm{C}\left(\sigma=13{ }^{\circ} \mathrm{C}\right)$, and pressures of 3.9-6.8 $\pm 3.2 \mathrm{kbar}$ (Table 6), with an average pressure of $5.7 \mathrm{kbar}(\sigma=1.3 \mathrm{kbar})$.

\section{Amphibole thermobarometry and oxybarometry}

Sample Cal-149Ta (light-brown lapilli): The thermometer of Ridolfi et al. (2010) gives temperatures of 894-922 $\pm 24^{\circ} \mathrm{C}$ (Fig. 10; Table 5), with an average temperature of $906^{\circ} \mathrm{C}(\sigma=$ $7^{\circ} \mathrm{C}$ ), a range and average which is slightly lower than those obtained by two-pyroxene thermometry. The pressure conditions obtained using the Ridolfi et al. (2010) barometer are 2$2.6 \pm 0.3 \mathrm{kbar}$ (Fig. 11; Table 5), with an average pressure of $2.3 \mathrm{kbar}(\sigma=0.1)$. The relative oxygen fugacity values given by the Ridolfi et al. (2010) oxygen barometer are between 0.2
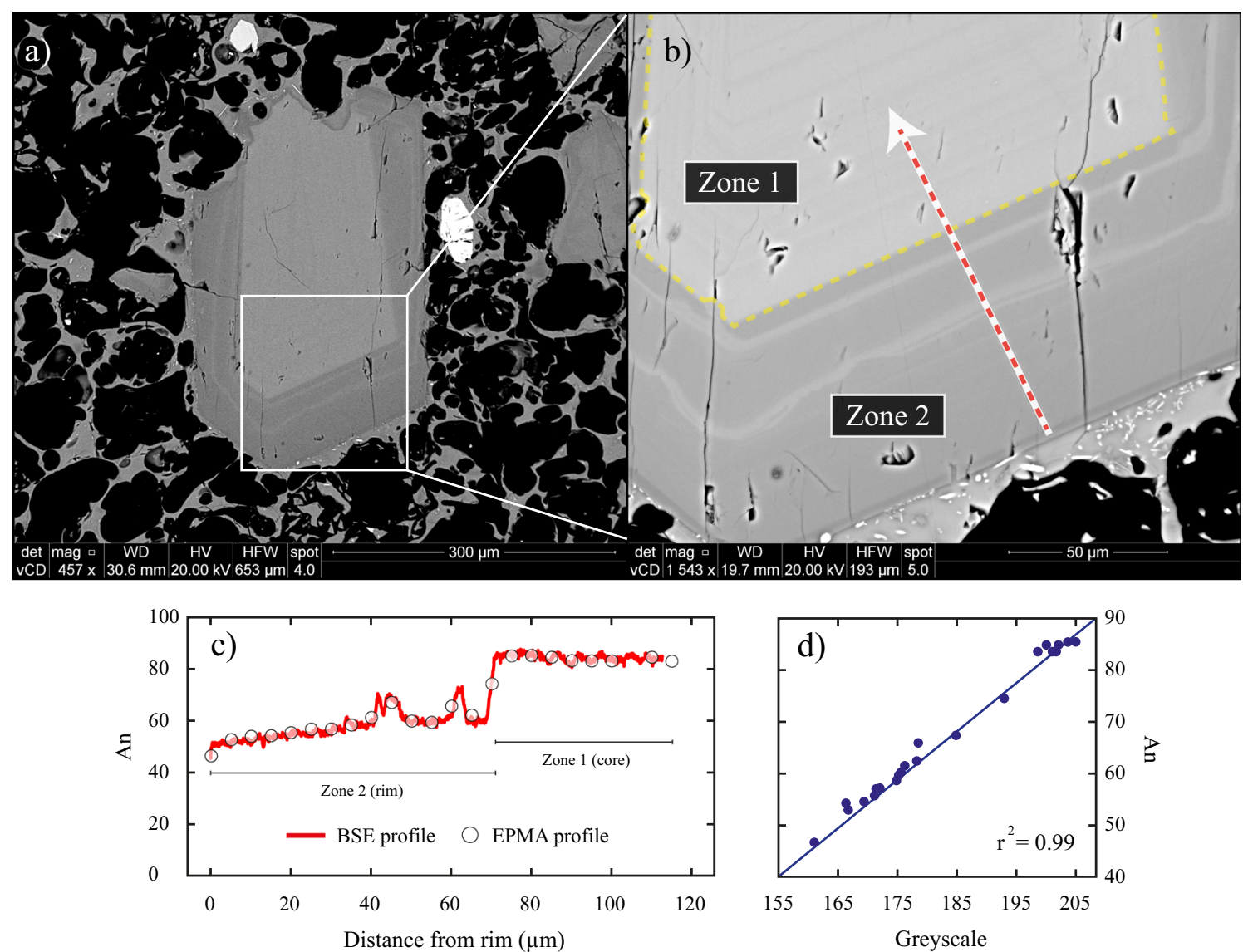

Figure 5 (a) Backscatter electron (BSE) image of a plagioclase crystal representative of group I. Brighter greyscale colours are correlated to higher density. (b) The arrow represents the profile measured by electron microprobe (EPMA) and its direction. (c) Anorthite profile composition $(\mathrm{An}=100 \times \mathrm{Ca} /(\mathrm{Ca}+\mathrm{Na}+\mathrm{K})$; elements in moles) by EPMA of the measured profile (circles) coupled with the $\mathrm{n}$ (BSE) profile based on greyscale values calibrated with the composition measured by electron microprobe

(solid line). (d) Relation and coefficient of determination $\left(r^{2}\right)$ between BSE profile and the measured anorthite content (An). Group I plagioclases have compositions corresponding to zone $1\left(\mathrm{An}_{80-92}\right)$ in the core and zone $2\left(\mathrm{An}_{46-79}\right)$ in the rims. 'An' represents the composition of plagioclases because in all crystals the $\mathrm{K}$ content is fairly constant (see Fig. 4) 

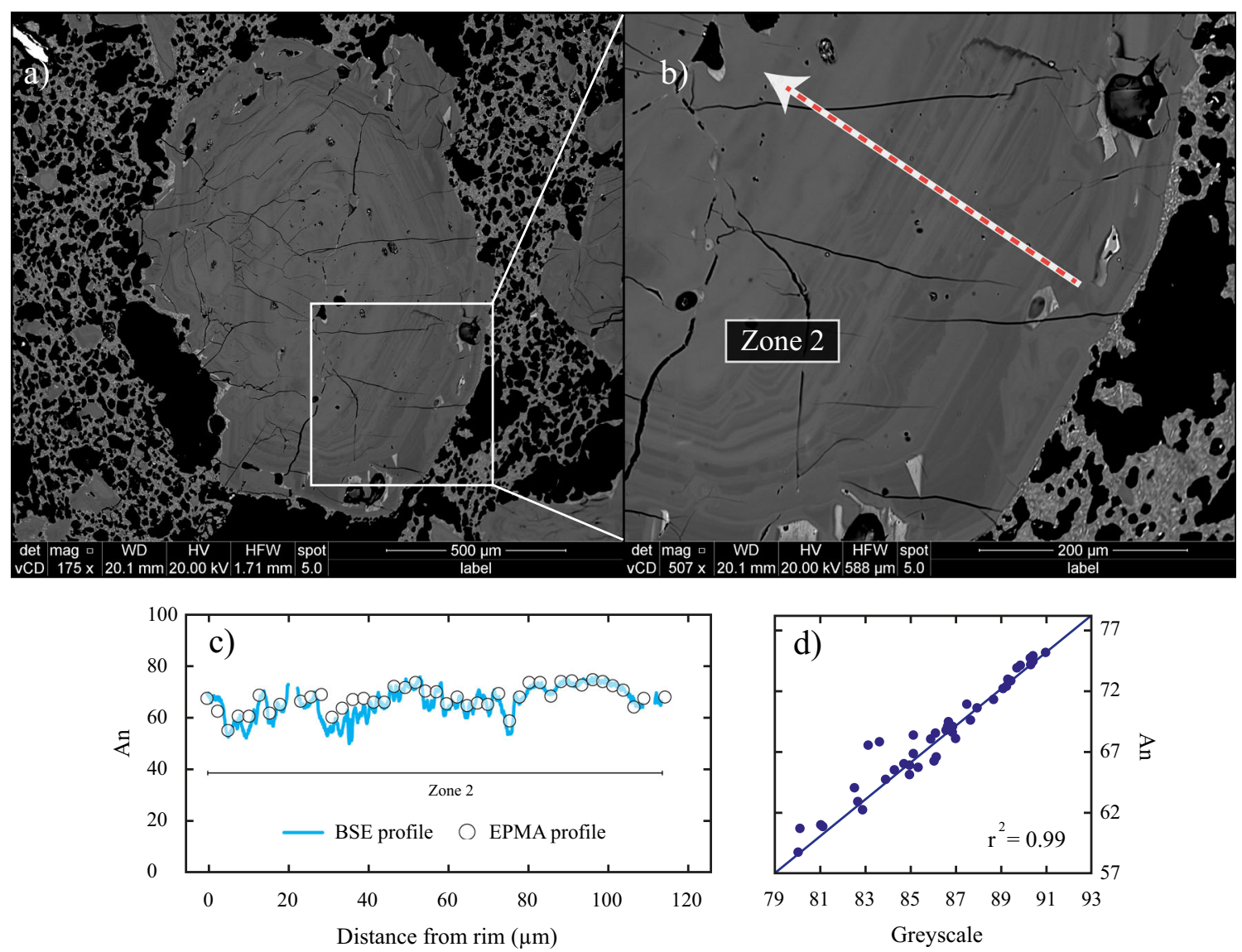

Figure 6 (a) Backscatter electron (BSE) image of a plagioclase crystal representative of group II. Brighter greyscale colours are correlated to higher density. (b) The arrow represents the profile measured by electron microprobe (EPMA) and its direction. Anorthite profile composition $(\mathrm{An}=100 \times \mathrm{Ca} /(\mathrm{Ca}+\mathrm{Na}+\mathrm{K})$; elements in moles) by EPMA of the measured profile (circles) coupled with the backscatter electron (BSE) profile

based on greyscale values calibrated with the composition measured by electron microprobe (solid line). (d) Relation and coefficient of determination $\left(r^{2}\right)$ between BSE profile and the measured anorthite content (An). Group II plagioclases have compositions corresponding to zone $2\left(\mathrm{An}_{46}\right.$ 79). 'An' is representing the composition of plagioclases because in all crystals the K content is fairly constant (see Fig. 4)

and $0.5( \pm 0.4) \Delta \mathrm{NNO}$ units (Table 5), with an average of 0.3 $\Delta$ NNO $(\sigma=0.1)$. The Ridolfi and Renzulli (2012) thermometer yields temperatures of $882-910 \pm 16{ }^{\circ} \mathrm{C}$ (Fig. 10; Table 5), with an average temperature of $897^{\circ} \mathrm{C}$
Figure 7 Amphibole compositions and classification (after Leake et al. 1997) of samples Cal-149Ta (grey circles) and Cal-160 (dark circles). All amphiboles of the sample Cal149Ta correspond to pargasites, whereas amphiboles of sample Cal-160 correspond to $70 \%$ edenites and $30 \%$ pargasites

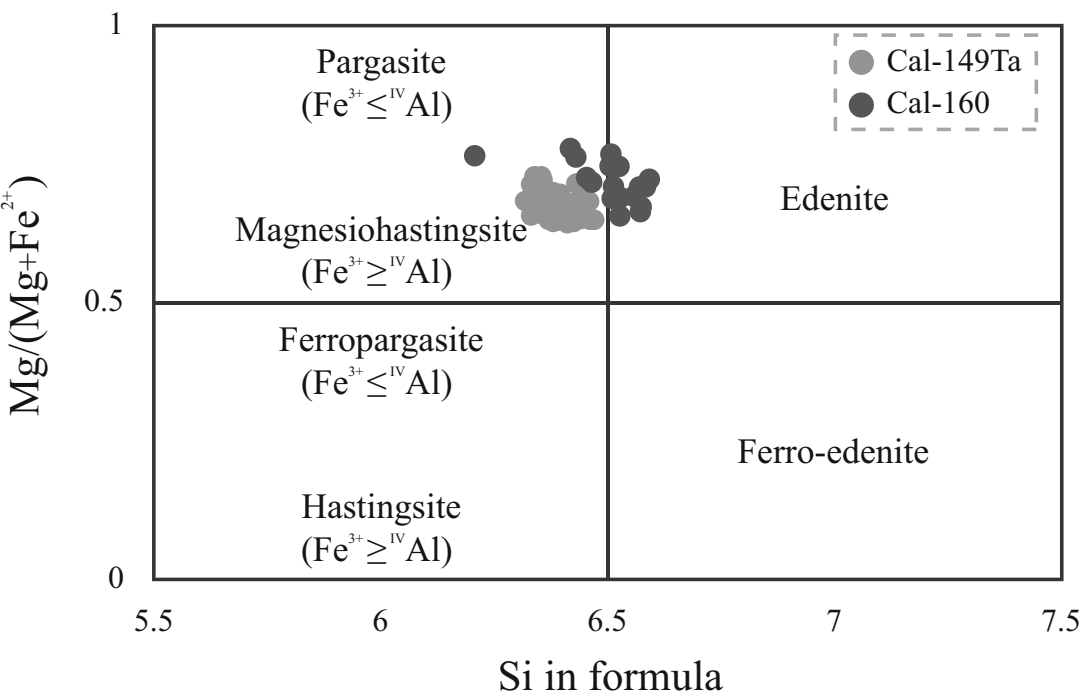


Figure 8 Olivine (found in all samples except Cal-160) and pyroxene (clino- and orthopyroxene, found in all samples, including Cal-160) compositions of the analysed samples
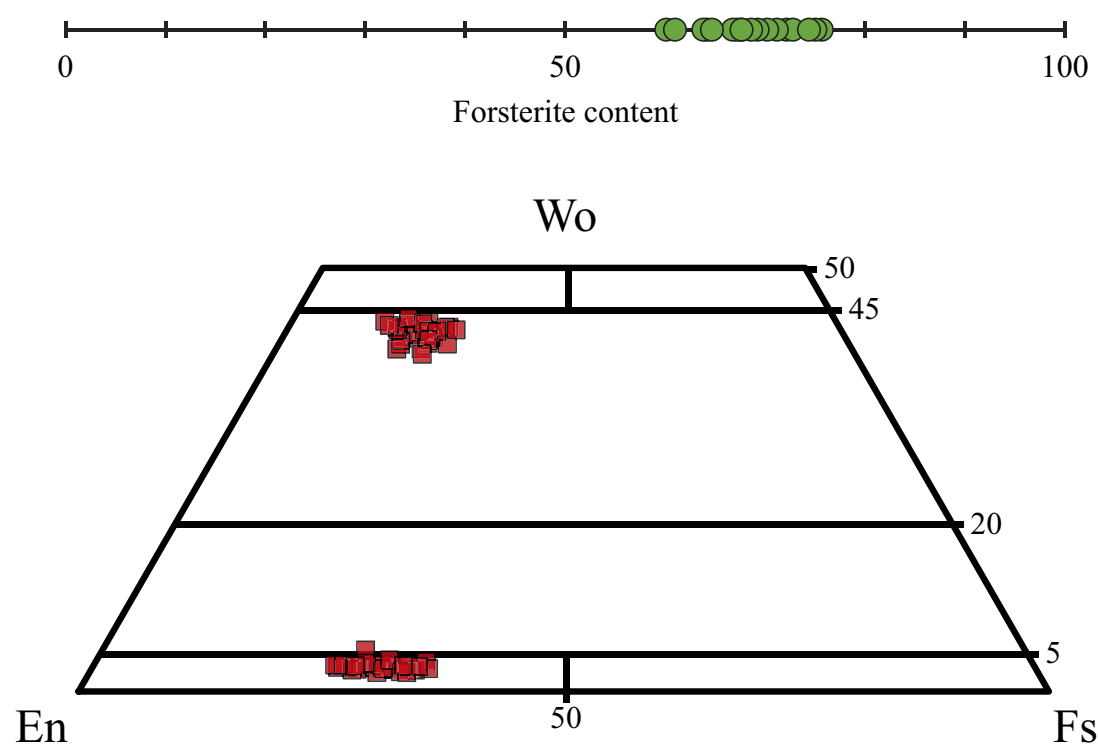

$\left(\sigma=7^{\circ} \mathrm{C}\right)$. For the same amphiboles, pressures of 1.9-2.3 \pm $0.4 \mathrm{kbar}$ (Fig. 11; Table 5), with an average of $2.1 \mathrm{kbar}(\sigma=$ $0.1 \mathrm{kbar}$ ), are obtained. The relative oxygen fugacities given by the Ridolfi and Renzulli (2012) oxygen barometer are between -0.9 and $-0.2 \Delta$ NNO (Table 5), with an average of $0.6 \Delta \mathrm{NNO}(\sigma=0.1)$.

Sample Cal-160 (white bomb): Temperatures obtained by the thermometer of Ridolfi et al. (2010) are $862-886 \pm 23{ }^{\circ} \mathrm{C}$ (Fig. 10; Table 6), similar to Cal-149Ta amphibole temperatures, with an average of $874{ }^{\circ} \mathrm{C}\left(\sigma=7^{\circ} \mathrm{C}\right)$. The Ridolfi et al. (2010) barometer gave pressures between 1.6 and $2 \pm 0.3 \mathrm{kbar}$ (Fig. 11; Table 6) and an average pressure of $1.8 \mathrm{kbar}(\sigma=$ $0.2 \mathrm{kbar}$ ). The relative oxygen fugacity values are between 0.2 and $0.5 \pm 0.4 \Delta$ NNO (Ridolfi et al. 2010; Table 6), with an average of $0.3 \Delta$ NNO $(\sigma=0.1)$. The Ridolfi and Renzulli (2012) thermometer gives temperatures of $823-859 \pm 23{ }^{\circ} \mathrm{C}$ (Fig. 10; Table 6) with an average of $842^{\circ} \mathrm{C}\left(\sigma=11^{\circ} \mathrm{C}\right)$. The same amphiboles gave pressures of 1.4-1.8 $\pm 0.4 \mathrm{kbar}$ (Fig. 11; Table 6), with an average pressure of $1.6 \mathrm{kbar}(\sigma=$ $0.1 \mathrm{kbar}$ ). According to the oxygen barometer of Ridolfi and Renzulli (2012), oxygen fugacity is between 0.4 and 0.8 $\triangle$ NNO (Table 6), with an average of $0.7 \Delta$ NNO $(\sigma=0.1)$.

\section{Plagioclase-amphibole thermometry}

Twelve pairs of amphibole-plagioclase in sample Cal-149Ta give equilibrium temperatures of $945-1018 \pm 42{ }^{\circ} \mathrm{C}$ (Fig. 10; Table 5), with an average temperature of $977^{\circ} \mathrm{C}\left(\sigma=26{ }^{\circ} \mathrm{C}\right)$. Sample Cal-160 gives lower equilibrium temperatures of 902-934 $\pm 42{ }^{\circ} \mathrm{C}$ (Fig. 10; Table 6) with an average temperature of $914^{\circ} \mathrm{C}\left(\sigma=18{ }^{\circ} \mathrm{C}\right)$. All these temperatures are higher than those obtained by the methods of Ridolfi et al. (2010) and Ridolfi and Renzulli (2012) based on single amphibole compositions.

\section{IImenite-titanomagnetite thermometry and oxygen barometry}

Ilmenite-titanomagnetite pairs are found only in samples Cal-149Tb (very scarcely), Cal-155 (very scarcely) and Cal-160 (common), and give temperature and oxygen fugacity values which all fell within the calibrated temperature and oxygen fugacity ranges of 800 to $1300{ }^{\circ} \mathrm{C}$, and -3 to $+3 \log$ units $\triangle N N O$, respectively. The core compositions gave large ranges of both temperature (841-966 $\pm 22{ }^{\circ} \mathrm{C}$; Fig. 10) and oxygen fugacity $(0.2-$ $0.75 \pm 0.9 \Delta \mathrm{NNO}$; Table 7 ); the rims give significantly different intensive conditions only in the sample Cal160, with calculated temperatures ranging from 900 to $1073{ }^{\circ} \mathrm{C}$ (Fig. 10) and oxygen fugacities from 0.2 to $0.75 \pm 0.1 \Delta$ NNO (Table 7 ). Details of intensive conditions related to each ilmenite-titanomagnetite pair and associated errors are given below and included in Table 7.

Samples Cal-149Tb and Cal-155: Temperatures are calculated from four core compositions of ilmenites and associated titanomagnetites considering diverse measurements (details in Online Resource 3). Individual pairs of grains show fairly constant compositions and, consequently, similar temperatures and oxygen fugacities, but different temperatures are obtained in different samples (see Table 7). For the sample Cal-149Tb, the temperatures are 961-1008 $\pm 22{ }^{\circ} \mathrm{C}$ (average $982{ }^{\circ} \mathrm{C}, \sigma=23{ }^{\circ} \mathrm{C}$ ) and oxygen fugacities are $0.36-0.45$ $\triangle \mathrm{NNO}$ (average $0.41 \Delta \mathrm{NNO}, \sigma=0.04$ ); for sample Cal155 , temperatures are 902-922 $\pm 22{ }^{\circ} \mathrm{C}$ (average $907{ }^{\circ} \mathrm{C}$, $\sigma=10^{\circ} \mathrm{C}$ ) and oxygen fugacities are 0.17-0.23 $\Delta \mathrm{NNO}$ (average $0.2 \Delta \mathrm{NNO}, \sigma=0.13$ ).

Sample Cal-160: In every crystal pair, compositions close to the boundary between these two mineral phases 

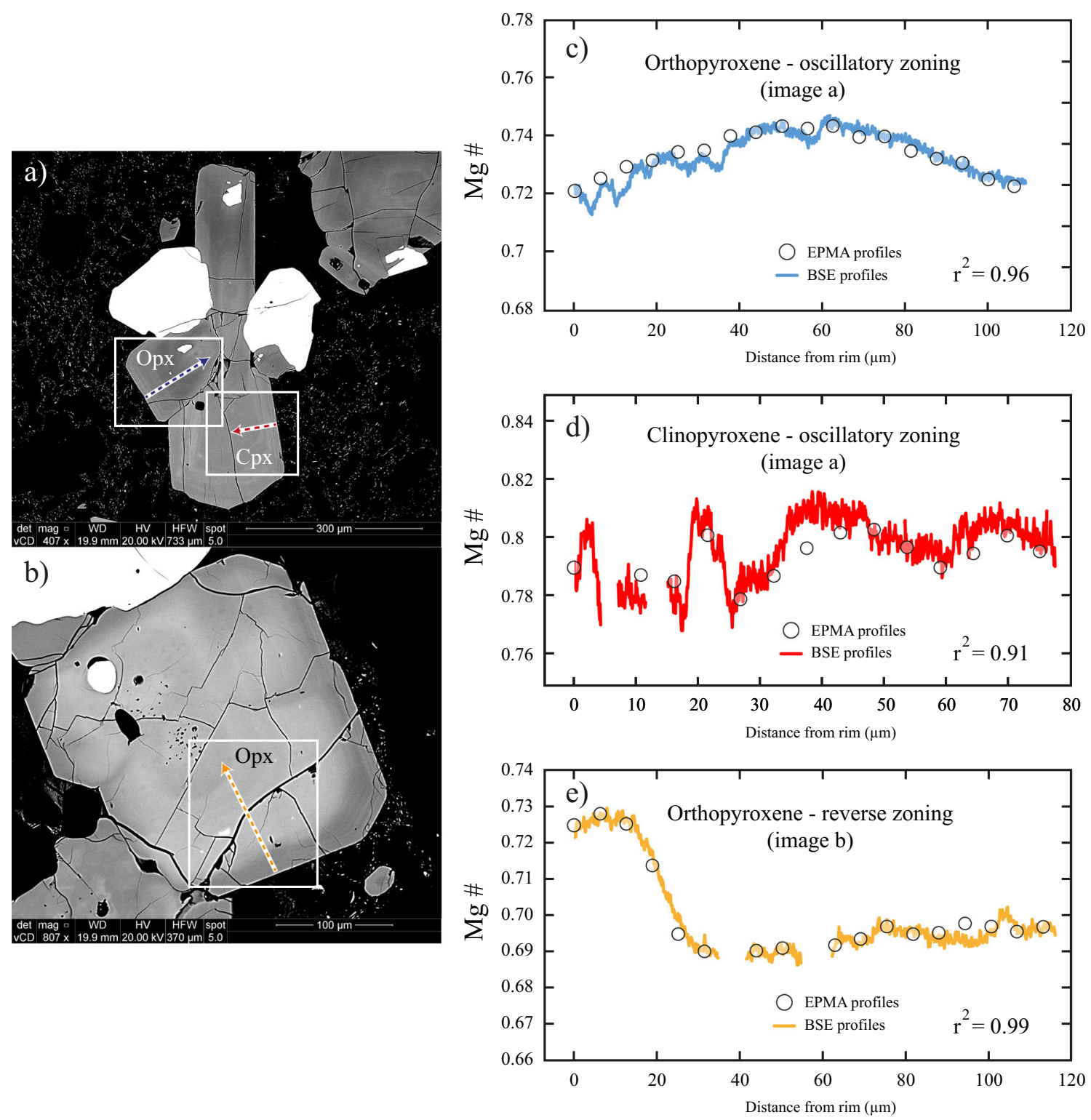

Figure 9 (a, b) Backscatter electron (BSE) images of clots of crystals where representative pyroxenes with oscillatory and reverse zonation patterns are found. Brighter greyscale colours are correlated to higher density. Arrows represent the measured profiles by electron microprobe (EPMA) and their directions. The orthopyroxene profile in (a) is shown in (c) and the clinopyroxene profile in (a) is shown in (d). The orthopyroxene profile in (b) is shown in (e). (c, d, e) $\mathrm{Mg} \#(\mathrm{Mg} \#=\mathrm{Mg}$ / $\left(\mathrm{Mg}+\mathrm{Fe}^{2+}\right)$; elements in moles) of the measured profile (circles) coupled with the backscatter electron (BSE) profile based on greyscale values calibrated with the composition measured by EPMA (solid line). The relation and coefficient of determination $\left(r^{2}\right)$ between BSE profile and the $\mathrm{Mg} \#$ measured content. Greyscale values represent $\mathrm{Mg} \#$ because the content of $\mathrm{Ca}$ within pyroxene crystals is fairly constant. $\mathrm{Mg} \#$ represents the composition of pyroxenes because in all crystals the $\mathrm{Ca}$ content is fairly constant (see Fig. 8) give considerably higher temperatures and slightly lower oxygen fugacity than core compositions (see Table 7). Cal-160 core temperatures are $841-894 \pm 17{ }^{\circ} \mathrm{C}$ (average $870{ }^{\circ} \mathrm{C}, \sigma=18{ }^{\circ} \mathrm{C}$ ) with oxygen fugacities of $0.5-0.94 \pm$ $0.09 \Delta \mathrm{NNO}$ (average $0.64 \Delta \mathrm{NNO}, \sigma=0.18$ ), whereas rim temperatures are $947-1073 \pm 23{ }^{\circ} \mathrm{C}$ (average $1018{ }^{\circ} \mathrm{C}, \sigma=45^{\circ} \mathrm{C}$ ) and oxygen fugacities are $0.21-$ $0.75 \pm 0.09 \Delta \mathrm{NNO}$ (average $0.48 \Delta \mathrm{NNO}, \sigma=0.16$ ).

\section{Ca-in-olivine thermometry}

Seven olivine cores give temperatures of $987-1019 \pm 22^{\circ} \mathrm{C}$ (Fig. 10; Table 5), with an average temperature of $997^{\circ} \mathrm{C}$ $\left(\sigma=13{ }^{\circ} \mathrm{C}\right)$. These Ca-in-olivine temperatures are therefore consistent with those obtained using the two-pyroxenes, $\mathrm{Fe}-\mathrm{Ti}$ oxides and plagioclase-amphibole thermometers for the same samples. 


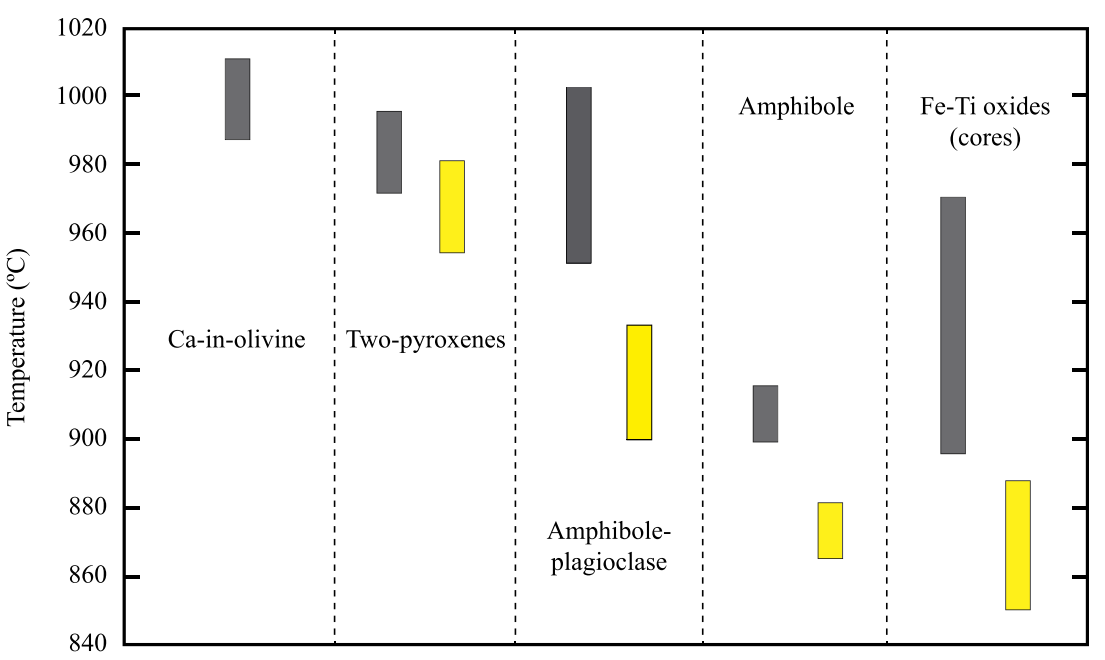

Fig. 10 Diagram showing the results of several thermometers (Ca-inolivine, Shejwalkar and Coogan 2013; two-pyroxenes, Brey and Köhler 1990; Putirka 2008; amphibole-plagioclase, Holland and Blundy 1994; amphibole, Ridolfi and Renzulli 2012; Fe-Ti oxides (cores), Ghiorso and Evans 2008). Vertical bars represent values of average temperature \pm one

\section{MELTS modelling}

The initial melt composition used in MELTS (Ghiorso and Sack 1995) modelling corresponds to the anhydrous groundmass composition of sample Cal-159 (Table 4) because it

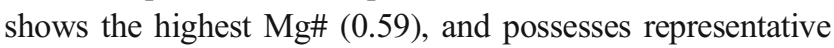
mineral assemblages and textural features observed in all April 2015 Calbuco products. The initial composition is calculated via an extraction of the modal composition of representative mineral phases from the whole-rock composition of the sample (Table 3). Details of the MELTS modelling results are available as Online Resource 4.

Zone 2 compositions of plagioclase phenocrysts (later rims and crystals) and the entire range of observed clinopyroxene and orthopyroxene compositions are reproduced by MELTS at conditions of $2-4 \%$ dissolved water, 2-6 kbar of pressure, temperatures from 900 to $1060{ }^{\circ} \mathrm{C}$ and crystallinity of 16$35 \mathrm{wt} . \%$. Conversely, the zone 1 composition of older plagioclase phenocryst cores and the remaining phases (notably amphibole, olivine and $\mathrm{Fe}-\mathrm{Ti}$ oxides) are not reproduced. standard deviation of all the samples except Cal-160 (grey) and Cal-160 (yellow). Sample Cal-160 gave temperatures systematically lower than the others. Ca-in-olivine was not used in sample Cal-160 because olivine was not found

Crystallisation modelling of the products gives a range of solid phases between 16 and 35 wt.\%. This range does not consider other mineral phases that could not be reproduced by MELTS (amphibole, olivine, ilmenite, titanomagnetite and zone 1 of plagioclase phenocrysts), which increases the crystallinity considerably (see details in Online Resource 4).

\section{Discussion}

All the April 2015 Calbuco samples studied here (including sample Cal-160) have characteristics typical of Calbuco's products documented previously for all the volcanic units by LópezEscobar et al. (1995b), Moreno et al. (2006), Sellés and Moreno (2011) and Daga et al. (2014). These include whole-rock chemistry, mineral assemblage and textural features (cf. Tables 1 and 2). Additionally, the trace-element data (Fig. 3c) show no significant differences in either elemental concentrations or distribution patterns across the whole sample suite (including Cal160). Of the whole-rock chemistry of the April 2015 Calbuco

Table 5 Calculated intensive conditions, methods and associated errors of the samples except Cal-160

\begin{tabular}{|c|c|c|c|c|c|c|c|c|c|c|c|}
\hline Method & References & $T\left({ }^{\circ} \mathrm{C}\right)$ & $\begin{array}{l}\text { Error } \\
( \pm)\end{array}$ & $\begin{array}{l}\text { Average } \\
\left({ }^{\circ} \mathrm{C}\right)\end{array}$ & $\begin{array}{l}\text { SD } \\
(\sigma)\end{array}$ & $\begin{array}{l}P \\
\text { (kbar) }\end{array}$ & $\begin{array}{l}\text { Error } \\
( \pm)\end{array}$ & $\begin{array}{l}\text { Average } \\
\text { (kbar) }\end{array}$ & $\begin{array}{l}\mathrm{SD} \\
(\sigma)\end{array}$ & $\begin{array}{l}\mathrm{fO}_{2} \\
\Delta \mathrm{NNO}\end{array}$ & $\begin{array}{l}\text { Error } \\
( \pm)\end{array}$ \\
\hline Two-pyroxenes & Putirka (2008) & $958-1013$ & 56 & 984 & 12 & $1.5-4.7$ & 3.2 & 3.3 & 0.8 & - & - \\
\hline \multirow[t]{2}{*}{ Amphibole } & Ridolfi et al. (2010) & $894-922$ & 24 & 906 & 7 & $2-2.6$ & 0.3 & 2.3 & 0.1 & $0.2-0.5$ & 0.4 \\
\hline & $\begin{array}{l}\text { Ridolfi and Renzulli } \\
\text { (2012) }\end{array}$ & $882-910$ & 16 & 897 & 7 & $1.9-2.3$ & 0.4 & 2.1 & 0.1 & $-0.9-0.2$ & - \\
\hline Plagioclase-amphibole & $\begin{array}{l}\text { Holland and Blundy } \\
\text { (1994) }\end{array}$ & $945-1018$ & 42 & 977 & 26 & - & - & - & - & - & - \\
\hline Ca-in-olivine & $\begin{array}{l}\text { Shejwalkar and } \\
\text { Coogan (2013) }\end{array}$ & 987-1019 & 22 & 997 & 13 & - & - & - & - & - & - \\
\hline
\end{tabular}


Table 6 Calculated intensive conditions, methods, and associated errors of the sample Cal-160

\begin{tabular}{|c|c|c|c|c|c|c|c|c|c|c|c|}
\hline Method & References & $\mathrm{T}\left({ }^{\circ} \mathrm{C}\right)$ & $\begin{array}{l}\text { error } \\
( \pm)\end{array}$ & $\begin{array}{l}\text { Average } \\
\left({ }^{\circ} \mathrm{C}\right)\end{array}$ & $\begin{array}{l}\text { Std. } \\
\text { Dev. }(\sigma)\end{array}$ & $\begin{array}{l}\mathrm{P} \\
\text { (kbar) }\end{array}$ & $\begin{array}{l}\text { error } \\
( \pm)\end{array}$ & $\begin{array}{l}\text { Average } \\
\text { (kbar) }\end{array}$ & $\begin{array}{l}\text { Std. } \\
\text { Dev. } \\
(\sigma)\end{array}$ & $\begin{array}{l}\mathrm{fO}_{2} \\
\Delta \mathrm{NNO}\end{array}$ & $\begin{array}{l}\text { error } \\
( \pm)\end{array}$ \\
\hline Two-pyroxenes & Putirka (2008) & $944-981$ & 56 & 968 & 13 & $3.9-6.8$ & 3.2 & 5.7 & 1.3 & - & - \\
\hline \multirow[t]{2}{*}{ Amphibole } & Ridolfi et al. (2010) & $862-886$ & 23 & 874 & 7 & $1.6-2.0$ & 0.3 & 1.8 & 0.2 & $0.2-0.5$ & 0.4 \\
\hline & $\begin{array}{l}\text { Ridolfi and } \\
\text { Renzulli (2012) }\end{array}$ & $823-859$ & 23 & 842 & 11 & $1.4-1.8$ & 0.4 & 1.6 & 0.1 & $0.4-0.8$ & - \\
\hline Plagioclase-amphibole & $\begin{array}{l}\text { Holland and Blundy } \\
\text { (1994) }\end{array}$ & $902-934$ & 42 & 914 & 18 & - & - & - & - & - & - \\
\hline
\end{tabular}

eruption presented here (55.6-56.9 wt.\% $\left.\mathrm{SiO}_{2}\right)$, the compositions are very similar to those reported for this eruption by Castruccio et al. (2016) for scoriaceous, pumiceous and dense juvenile products $\left(54.5-58.1 \mathrm{wt} . \% \mathrm{SiO}_{2}\right)$. Further, the composition of the products analysed here are chemically within the
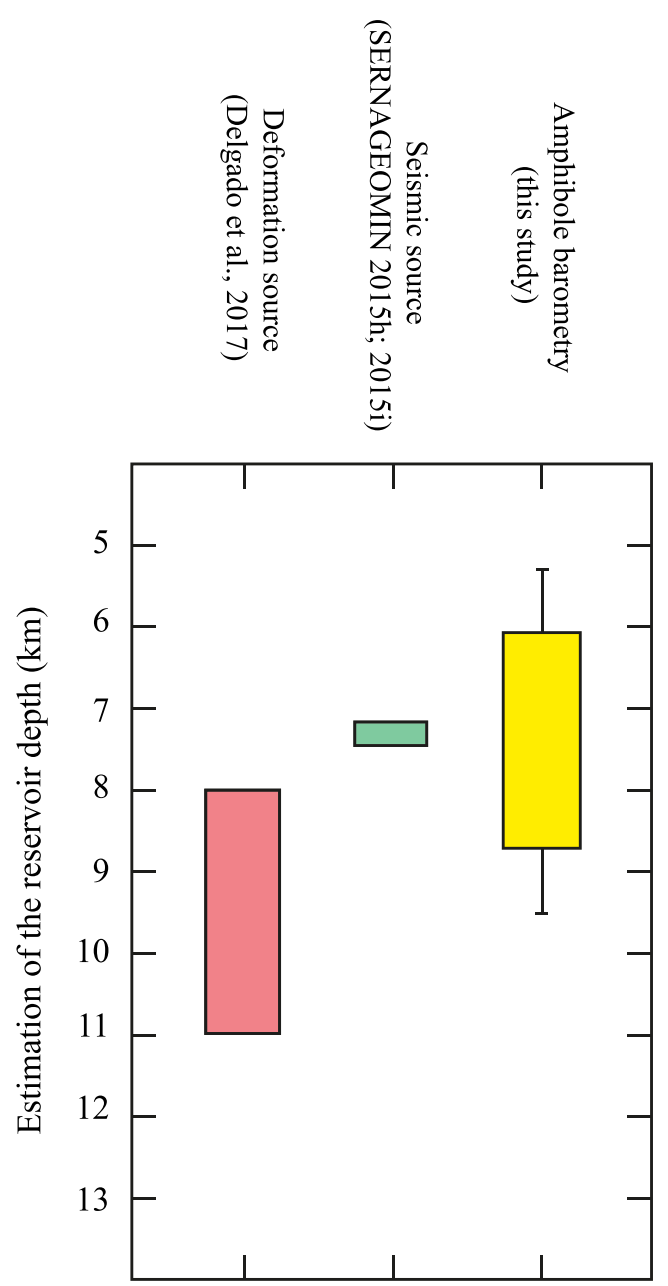

Fig. 11 Comparison of different methods that allow the estimation of the reservoir depth: amphibole barometry (yellow bar and including errors; this study), seismic source (green bar; SERNAGEOMIN 2015h, 2015i) and deformation source (red bar; Delgado et al. 2017). The full barometry depth range is from 5.5 to $11 \mathrm{~km}$ (considering different pressure condition approaches) and corresponds to upper-to-middle crust conditions range of older units (unit 1-50.5-60.3 wt.\% $\mathrm{SiO}_{2}$, unit 257.1-61 wt.\% $\mathrm{SiO}_{2}$, unit 3-54.3-64.5 wt.\% $\mathrm{SiO}_{2}$; LópezEscobar et al. 1995b; Sellés and Moreno 2011) and other deposits of unit 4 (54.8-58.6 wt.\% $\mathrm{SiO}_{2}$; López-Escobar et al. 1995b). The mineral assemblage has been fairly constant during the history of the volcano (Sellés and Moreno 2011), it being composed of plagioclase, clinopyroxene, orthopyroxene, amphibole, ilmenite, titanomagnetite and olivine (see Table 1), the latter always being surrounded by pyroxenes, plagioclase and Fe-Ti oxides.

\section{Mush reservoir in the upper crust}

The Calbuco volcanic products of 2015 possess several features that have been regarded as consistent with mush-zone magma storage, in the manner proposed by, for example, Hildreth (2004) and Bachmann and Bergantz (2006). These features include high crystallinity ( 40-60 vol.\%) of the volcanic products (cf. Hildreth 2004; Bachmann and Bergantz 2006), the presence of clots of crystals where interstitial glasses are locally well preserved and compositionally different from the outer glasses (e.g. Saunders et al. 2010; Passmore et al. 2012; Spera and Bohrson 2018) and the presence of complex textural features that suggest episodes of reequilibration (cf. Moore et al. 2014). Although only small compositional ranges are recognised here for Calbuco in plagioclase, pyroxene and amphibole, the complex mineralogical textures commonly observed indicate a prolonged history of crystallisation and with changes in either temperature, pressure, melt composition, oxygen fugacity or other intensive variables through a protracted period of time (see Figs. 5, 6 and 9).

Our assumption that at the Cal-159 groundmass is a reasonable proxy for the melt composition in equilibrium with the crystal mush is supported by the MELTS modelling which can reproduce the compositions of the dominant crystal phases of plagioclase (zone 2), ortho- and clino-pyroxene. Pressure ranges obtained via amphibole barometry (considering average and standard deviation pressures) suggest the location of the mush reservoir at shallow depth. The barometer calibrated by Ridolfi et al. (2010) gives pressures equivalent to 
Table 7 Fe-Ti oxide core (pre-heating) and rim (during heating) intensive conditions rank ordered by core temperature

\begin{tabular}{|c|c|c|c|c|c|c|c|c|c|c|c|c|c|}
\hline Sample & Pair & Place & $T\left({ }^{\circ} \mathrm{C}\right)$ & SD & Error & $\begin{array}{l}\mathrm{fO}_{2} \\
(\Delta \mathrm{NNO})\end{array}$ & SD & Error & Place & $T\left({ }^{\circ} \mathrm{C}\right)$ & Error & $\begin{array}{l}\mathrm{fO}_{2} \\
(\Delta \mathrm{NNO})\end{array}$ & Error \\
\hline 160 & Fig1_p2 & Core & 841 & 6 & 12 & 0.94 & 0.05 & 0.04 & Rim & 1041 & 14 & 0.55 & 0.04 \\
\hline 160 & Fig1_p1 & Core & 841 & 7 & 12 & 0.91 & 0.03 & 0.04 & Rim & 1067 & 17 & 0.5 & 0.05 \\
\hline 160 & Fig1_p3 & Core & 846 & 4 & 12 & 0.9 & 0.02 & 0.04 & Rim & 1005 & 15 & 0.56 & 0.05 \\
\hline 160 & Figh_p1 & Core & 865 & 8 & 15 & 0.5 & 0.06 & 0.09 & Rim & 1068 & 15 & 0.64 & 0.03 \\
\hline 160 & Figf_p1 & Core & 868 & 11 & 16 & 0.49 & 0.03 & 0.09 & Rim & 1073 & 23 & 0.21 & 0.09 \\
\hline 160 & Figf_p2 & Core & 870 & 1 & 17 & 0.45 & 0.01 & 0.09 & Rim & 947 & 19 & 0.27 & 0.09 \\
\hline 160 & Figb_p1 & Core & 879 & 8 & 17 & 0.44 & 0.1 & 0.09 & Rim & 952 & 18 & 0.32 & 0.09 \\
\hline 160 & Figex_p1 & Core & 879 & 13 & 15 & 0.55 & 0.06 & 0.07 & Rim & 1015 & 18 & 0.43 & 0.06 \\
\hline 160 & Fig $13 \_p 2$ & Core & 879 & 7 & 15 & 0.61 & 0.03 & 0.08 & Rim & 1013 & 15 & 0.61 & 0.05 \\
\hline 160 & Fig17_p4 & Core & 883 & 8 & 16 & 0.55 & 0.03 & 0.07 & Rim & 963 & 17 & 0.47 & 0.08 \\
\hline 160 & Fig17_p2 & Core & 892 & 6 & 15 & 0.59 & 0.03 & 0.07 & Rim & 1048 & 14 & 0.75 & 0.03 \\
\hline 160 & Fig17_p1 & Core & 894 & 14 & 15 & 0.66 & 0.08 & 0.07 & Rim & 1029 & 19 & 0.4 & 0.07 \\
\hline 155 & Fig3_p1 & Core & 903 & 17 & 20 & 0.21 & 0.11 & 0.12 & Rim & 922 & 21 & 0.23 & 0.12 \\
\hline 155 & Fig24_p1 & Core & 902 & 18 & 21 & 0.17 & 0.1 & 0.13 & Rim & 900 & 22 & 0.2 & 0.13 \\
\hline $149 \mathrm{~Tb}$ & Fig14_p2 & Core & 961 & 6 & 22 & 0.36 & 0.02 & 0.1 & Rim & 1008 & 22 & 0.45 & 0.09 \\
\hline $149 \mathrm{~Tb}$ & Fig14_p1 & Core & 966 & 6 & 22 & 0.39 & 0.03 & 0.1 & Rim & 996 & 21 & 0.45 & 0.09 \\
\hline
\end{tabular}

'5.8-9.5 km depths, while the barometer calibrated by Ridolfi and Renzulli (2012) gives pressures equivalent to 5.1-8.4 km depths (each considering a crustal density of $2.8 \mathrm{~g} / \mathrm{cm}^{3}$; Fowler 2005). These depth ranges have some degree of overlap with the source of co-eruptive subsidence located between 8 and $11 \mathrm{~km}$ depth by Delgado et al. (2017). In addition, the barometry results are consistent with the source related to the seismic swarm that occurred a few hours before the eruption, this being a VT event of depth between 7.1 and $7.4 \mathrm{~km}$ (SERNAGEOMIN 2015h, i). A summary of inferred depths for the reservoir that fed the eruption is given in Fig. 11. The shallow reservoir suggested in this figure would belong to upper crustal magma storage (Tašárová 2007). This is distinct from the crystallisation of crustal xenoliths at 6-8 kbar (equivalent to depths of 21 to $28 \mathrm{~km}$ ) reported by Hickey-Vargas et al. (1995) based on amphibole barometry on samples of the 1961 eruption. These results suggest middle to lower crustal storage of the 1961 magma. In several volcanic complexes of the Southern Andes, mush magma reservoirs have been recognised in the upper crust (e.g. at Llaima, Bouvet de Maisonneuve et al. 2012; and Quetrupillán, Brahm et al. 2018). Shallow reservoirs in the Southern Volcanic Zone of the Andes have also been inferred via changes in rigidity of the upper crust (Morgado et al. 2017) and the compressive intra-arc tectonic setting (Cembrano and Lara 2009; Chaussard and Amelung 2012). Together, these results suggest that a complex system of chambers extending from deep to shallow levels may be commonplace at Andean volcanoes.

\section{Shape and heterogeneity of the reservoir}

Delgado et al. (2017) have suggested a prolate, pressurised spheroid shape for the reservoir beneath Calbuco volcano via modelling of the co-eruptive subsidence signal. According to the time-dependent numerical modelling of an evolving magma chamber by Gutiérrez and Parada (2010), thermal heterogeneities are much more likely in stock-like than sill-shaped chambers. Considering longterm thermometry (via two-pyroxenes, amphibole-plagioclase, amphibole and Ca-in-olivine geothermometers; see Tables 5 and 6), sample Cal-160 shows systematically lower temperatures than all other samples (Fig. 10). Fe-Ti oxides thermometry is commonly used to estimate immediately pre-eruptive temperatures (this being 'short-term thermometry'-Ruprecht and Bachmann 2010; Brahm et al. 2018), and here sample Cal-160 shows systematically lower temperatures for core-core equilibria of in-contact ilmenitetitanomagnetite pairs (see Table 7).

According to Gutiérrez and Parada (2010), in modelling of stock-like reservoirs, the highest temperatures related to crystallinities of between 30 and $40 \mathrm{vol} . \%$ are found in the middle of the reservoir. This is a feature of all samples except Cal160. Instead, lower temperatures related to crystallinities of $60 \mathrm{vol} . \%$ are found at the bottom of the reservoir, as is consistent with features of sample Cal-160. In addition, sample Cal-160 is slightly more evolved than all other samples (lower $\mathrm{Mg \#}$ and higher $\mathrm{SiO}_{2}$ wt.\%; see Fig. 3). This, according to the Gutiérrez and Parada (2010) modelling, is also consistent with the location of Cal-160 in the lower zone or at the borders of the magma chamber. 


\section{Local-scale heating}

In-contact ilmenite-titanomagnetite pairs exchange elements (e.g. $\mathrm{Fe}^{2+}+\mathrm{Ti}^{4+} \leftrightarrow 2 \mathrm{Fe}^{3+}$; Ghiorso and Sack 1991) across the interface, which can be used as thermometer and oxygen barometer (Ghiorso and Evans 2008; Sauerzapf et al. 2008). As a consequence, such boundaries respond rapidly to changes in the intensive physical properties of temperature and/or oxygen fugacity within the reservoir (Lasaga 1983). Therefore, we can postulate that crystal core compositions may represent older, relatively long-term temperatures, whereas rim compositions give information of changes of temperature over a short timescale immediately before eruption.

Rim compositions (close to the interface of the crystal pairs) yield considerably higher temperatures than core compositions only in the sample Cal-160 (70 to $220^{\circ} \mathrm{C}$ higher relative to crystal cores; Table 7). The remaining samples show similar $\mathrm{Fe}-\mathrm{Ti}$ oxides temperatures for cores and rims, with no late heating stage. Additionally, the compositional zonations in orthopyroxene, clinopyroxene and plagioclase phenocrysts (see Figs. 5, 6 and 9) are within the crystal clots as well as in contact with the groundmass, suggesting these zonings were inherited from the crystal mush development stage. This development period would not be associated with zoning due to an ionic exchange as response to the same heating as $\mathrm{Fe}-\mathrm{Ti}$ oxides recorded because the silicate phases have much lower ionic diffusivities and record older stages of the evolution of the system.
Sample Cal-160 is unique across the sampled deposits as being the only material that records evidence of heating. Its composition and crystallinity make it representative of the bottom of the mush reservoir. The heating that this sample records seems both localised and intense, consistent with an input of hotter magma. Underlying recharge of hot magma has been suggested as a trigger for many eruptions of Southern Andean shallow reservoirs (e.g. Quizapu, Ruprecht and Bachmann 2010; Villarrica, Lohmar et al. 2012, Morgado et al. 2015). Some eruptions have also involved the presence of a mush zone (e.g. Llaima, Bouvet de Maisonneuve et al. 2012; Quetrupillán, Brahm et al. 2018). The nature and extent of magma mixing in such situations has been further proposed to influence eruptive style: Ruprecht and Bachmann (2010) suggested that increasing degrees of magma mixing (between felsic magma and a more mafic recharge) decreases the fragmentation efficiency and magma viscosity, and thus favours effusive eruptions. Restricted compositional interaction between the new magma influx and an overlying crystal mush could occur because of the mush acting (at least initially) as a rheological barrier (Huber et al. 2009; Kent et al. 2010) or because of the occurrence of a volatile layer between the hot magma and the crystal mush (Bachmann and Bergantz 2006; Huber et al. 2010b; Parmigiani et al. 2014; Schleicher and Bergantz 2017; Spera and Bohrson 2018). In this situation, only small magma volumes could

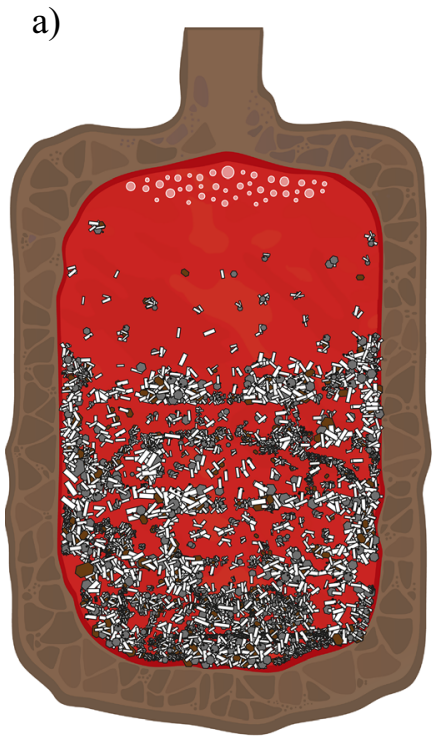

No significant perturbations in the magma reservoir

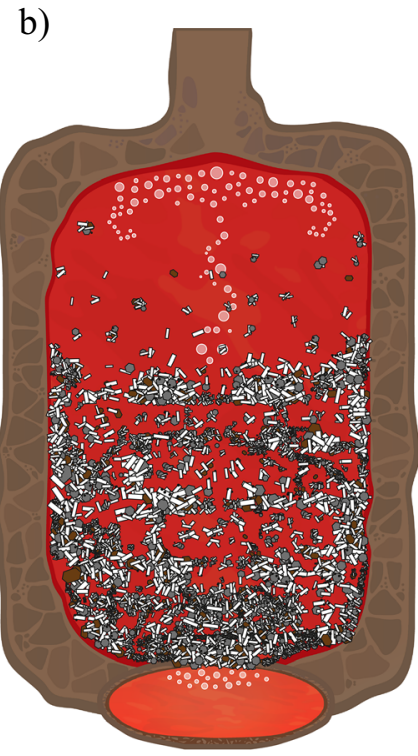

Arrival of a new, hotter magma

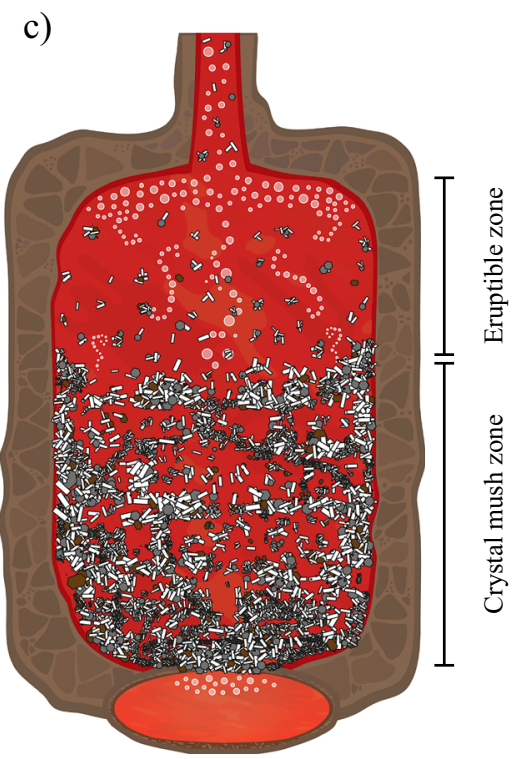

The eruption is triggered
Fig. 12 Schematic representation of the shape, and evolution in time, of the magma reservoir beneath Calbuco volcano; (a) represents the reservoir, including a mush zone at the bottom, before the input of new magma; (b) represents the arrival of the new, hotter magma generating a local-scale heating; (c) represents the moment of eruption triggering 
be reheated, favouring explosive eruptions (cf. Couch et al. 2001; Ruprecht and Bachmann 2010). Data presented here suggest that this was the case for the April 2015 Calbuco eruption. Our results are consistent with those from Castruccio et al. (2016) who, based on stratigraphy and whole-rock geochemistry, suggested that the April 2015 Calbuco eruption was triggered by either volatile exsolution or a moderate-sized magmatic intrusion of a new magma into the base of the reservoir with almost no mixing effects.

\section{Conclusions}

The 2015 Calbuco eruption is an example of a shallow, crystal-rich magma reservoir feeding a moderate-sized eruption $\left(\sim 0.3-0.6 \mathrm{~km}^{3}\right.$ erupted products, non-DRE). Based on textural and compositional criteria of nine representative samples, we conclude the existence of a mush reservoir, which amphibole barometry indicates to lie within the upper to middle crust (at 5.5-9.5 km depth), consistent with previous works (SERNAGEOMIN 2015h, i; Delgado et al. 2017).

A prolate spheroid shape of the reservoir has been inferred from previous studies and, based on detailed thermobarometry, crystallinity and the compositions of nine representative samples, we infer that all samples of this study (except Cal-160) are derived from the middle of a mush reservoir. Sample Cal-160 represents a portion of the rheologically rigid basal envelope. In addition, based on $\mathrm{Fe}-\mathrm{Ti}$ oxide (ilmenite and titanomagnetite) thermometry and textural features of the crystal-clot-rich Cal-160 sample, we identify a localised heating event of 70 $220{ }^{\circ} \mathrm{C}$, reaching potentially as high as $1070{ }^{\circ} \mathrm{C}$. This mobilised magma represented by Cal-160, an event which we infer to be linked to eruption triggering (Fig. 12) and that would have affected only the magma reservoir at its highly crystalline (mush) base. The absence of a heating record in the remaining samples suggests that all other magma remained thermally and chemically unaffected by the trigger pulse during eruption. This emphasises the need for rapid warning systems to communicate hazards rapidly to the local population.

Acknowledgements We acknowledge the help in the field of Marcela Vollmer. We acknowledge Richard Walshaw for assistance with the EPMA, and Duncan Hedges who provided assistance with the SEM at the University of Leeds. Financial support through FONDAP project 15090013 (Centro de Excelencia en Geotermia de los Andes, CEGA), CONICYT MSc fellowship $(22141497, \mathrm{RB})$ and CONICYT PhD fellowship (72160268, EM) are acknowledged. We would like to specially thank to Claire Harnett. We thank two anonymous reviewers for their detailed and constructive comments. Editorial handling and constructive comments of L. Pioli and A. Harris are greatly appreciated.
Open Access This article is distributed under the terms of the Creative Commons Attribution 4.0 International License (http:// creativecommons.org/licenses/by/4.0/), which permits unrestricted use, distribution, and reproduction in any medium, provided you give appropriate credit to the original author(s) and the source, provide a link to the Creative Commons license, and indicate if changes were made.

\section{References}

Adriasola AC, Thomson SN, Brix MR, Hervé F, Stöckhert B (2006) Postmagmatic cooling and late Cenozoic denudation of the north Patagonian batholith in the Los Lagos region of Chile, 41-42 15' S. Int J Earth Sci 95(3):504-528. https://doi.org/10.1007/s00531005-0027-9

Aggarwal S, Dieckmann R (2002a) Point defects and cat ion tracer diffusion in $\left(\mathrm{Ti}_{\mathrm{x}} \mathrm{Fe}_{1-\mathrm{x}}\right)_{3-\delta} \mathrm{O}_{4}$. 1. Non-stoichiometry and point defects. Phys Chem Miner 29(10):695-706. https://doi.org/10.1007/s00269002-0282-2

Aggarwal S, Dieckmann R (2002b) Point defects and cation tracer diffusion in $\left(\mathrm{Ti}_{\mathrm{x}} \mathrm{Fe}_{1-\mathrm{x}}\right)_{3-\delta} \mathrm{O}_{4}$. II. Cation tracer diffusion. Phys Chem Miner 29(10):707-718. https://doi.org/10.1007/s00269-002-0284-0

Aragon R, McCallister RH, Harrison HR (1984) Cation diffusion in titanomagnetites. Contrib Mineral Petr 85(2):174-185. https://doi. org/10.1007/BF00371707

Bachmann O, Bergantz GW (2004) On the origin of crystal-poor rhyolites: extracted from a batholithic crystal mushes. J Petrol 45(8): 1565-1582. https://doi.org/10.1093/petrology/egh019

Bachmann O, Bergantz GW (2006) Gas percolation in upper-crustal silicic crystal mushes as a mechanism for upward heat advection and rejuvenation of near-solidus magma bodies. J Volcanol Geotherm Res 149(1):85-102. https://doi.org/10.1016/j.jvolgeores.2005.06.002

Bachmann O, Bergantz G (2008) The magma reservoirs that feed supereruptions. Elements 4(1):17-21. https://doi.org/10.2113/ GSELEMENTS.4.1.17

Bouvet De Maisonneuve C, Dungan MA, Bachmann O, Burgisser A (2012) Insights into shallow magma storage and crystallization at Volcán Llaima (Andean southern volcanic zone, Chile). J Volcanol Geotherm Res 211:76-91. https://doi.org/10.1016/j.jvolgeores. 2011.09.010

Brahm R, Parada MA, Morgado E, Contreras C, McGee L (2018) Origin of trachyte lavas of the Quetrupillán volcanic complex, Chile ( $39^{\circ} 30^{\prime}$ S): examples of residual melts in rejuvenated crystalline mush reservoir. J Volcanol Geotherm Res 357:163-176. https:// doi.org/10.1016/j.jvolgeores.2018.04.020

Brey GP, Köhler T (1990) Geothermobarometry in four-phase Lherzolites II. New thermobarometers, and practical assessment of existing thermobarometers. J Petrol 31(6):1353-1378. https://doi.org/10. 1093/petrology/31.6.1353

Burgisser A, Bergantz GW (2011) A rapid mechanism to remobilize and homogenize highly crystalline magma bodies. Nature 471:212-216. https://doi.org/10.1038/nature09799

Castruccio A, Clavero J, Rivera A (2010) Comparative study of lahars generated by the 1961 and 1971 eruptions of Calbuco and Villarrica volcanoes, southern Andes of Chile. J Volcanol Geotherm Res 190(3-4):297-311. https://doi.org/10.1016/j. jvolgeores.2009.12.005

Castruccio A, Clavero J, Segura A, Samaniego P, Roche O, Le Pennec J, Droguett B (2016) Eruptive parameters and dynamics of the April 2015 sub-Plinian eruptions of Calbuco volcano (southern Chile). Bull Volcanol 327:469-483. https://doi.org/10.1007/s00445-0161058-8 
Cembrano J, Lara L (2009) The link between volcanism and tectonics in the southern volcanic zone of the Chilean Andes: a review. Tectonophysics 471(1-2):96-113. https://doi.org/10.1016/j.tecto. 2009.02.038

Cembrano J, Hervé F, Lavenu A (1996) The Liquine Ofqui fault zone: a long-lived intra-arc fault system in southern Chile. Tectonophysics 259(1-3):55-66. https://doi.org/10.1016/0040-1951(95)00066-6

Cembrano J, Schermer E, Lavenu A, Sanhueza A (2000) Contrasting nature of deformation along an intra-arc shear zone, the LiquiñeOfqui fault zone, southern Chilean Andes. Tectonophysics 319: 219-149. https://doi.org/10.1016/S0040-1951(99)00321-2

Chaussard E, Amelung F (2012) Precursory inflation of shallow magma reservoirs at west Sunda volcanoes detected by InSAR. Geophys Res Lett 39(21). https://doi.org/10.1029/2012GL053817

Claiborne LL, Miller CF, Flanagan DM, Clynne MA, Wooden JL (2010) Zircon reveals protracted magma storage and recycling beneath Mount St. Helens. Geology 38(11):1011-1014. https://doi.org/10. 1130/G31285.1

Cooper KM, Kent AJ (2014) Rapid remobilization of magmatic crystals kept in cold storage. Nature 506(7489):480-483. https://doi.org/10. 1038/nature12991

Cooper GF, Morgan DJ, Wilson CJ (2017) Rapid assembly and rejuvenation of a large silicic magmatic system: insights from mineral diffusive profiles in the kidnappers and Rocky Hill deposits, New Zealand. Earth Planet Sci Lett 473:1-13. https://doi.org/10.1016/j. eps1.2017.05.036

Couch S, Sparks RSJ, Carroll MR (2001) Mineral disequilibrium in lavas explained by convective self-mixing in open magma chambers. Nature 411(6841):1037-1039. https://doi.org/10.1038/35082540

Daga R, Ribeiro Guevara S, Poire DG, Arribére M (2014) Characterization of tephras dispersed by the recent eruptions of volcanoes Calbuco (1961), Chaitén (2008) and Cordón Caulle complex (1960 and 2011), in northern Patagonia. J S Am Earth Sci 49:1-14. https://doi.org/10.1016/j.jsames.2013.10.006

Dalton JA, Lane SJ (1996) Electron microprobe analysis of Ca in olivine close to grain boundaries: the problem of secondary X-ray fluorescence. Am Mineral 81(1-2):194-201. https://doi.org/10.2138/am1996-1-224

Delgado F, Pritchard ME, Ebmeier S, González P, Lara L (2017) Recent unrest (2002-2015) imaged by space geodesy at the highest risk Chilean volcanoes: Villarrica, Llaima, and Calbuco (southern Andes). J Volcanol Geotherm Res 344:270-288. https://doi.org/10. 1016/j.jvolgeores.2017.05.020

Dohmen R, Chakraborty S (2007a) Fe-Mg diffusion in olivine I: experimental determination between 700 and $1,200{ }^{\circ} \mathrm{C}$ as a function of composition, crystal orientation and oxygen fugacity. Phys Chem Miner 34:389-407. https://doi.org/10.1007/s00269-007-0157-7

Dohmen R, Chakraborty S (2007b) Fe-Mg diffusion in olivine II: point defect chemistry, change of diffusion mechanisms and a model for calculation of diffusion coefficients in natural olivine. Phys Chem Miner 34:409-430. https://doi.org/10.1007/s00269-007-0158-6

Dohmen R, Ter Heege JH, Becker HW, Chakraborty S (2016) Fe-Mg interdiffusion in orthopyroxene. Am Mineral 101(10):2210-2221. https://doi.org/10.2138/am-2016-5815

Droop GTR (1987) A general equation for estimating $\mathrm{Fe}^{3+}$ concentrations in ferromagnesian silicates and oxides from microprobe analyses, using stoichiometric criteria. Mineral Mag 51:431-435

Fischer O (1893) Erupción del volcán Calbuco, Santiago. Anales de la Universidad de Chile LXXXV, pp 197-204

Fowler CMR (2005) The solid earth: an introduction to global geophysics, 2nd edn. Cambridge University Press, Cambridge

Ganguly J, Tazzoli V (1994) $\mathrm{Fe}^{2+}-\mathrm{Mg}$ interdiffusion in orthopyroxene: retrieval from the data on intracrystalline exchange reaction. Am Mineral 79(9-10):930-937

Ghiorso MS, Evans BW (2008) Thermodynamics of rhombohedral oxide solid solutions and a revision of the $\mathrm{Fe}$-Ti two-oxide geothermometer and oxygen-barometer. Am J Sci 308:957-1039. https://doi.org/10.2475/09.2008.01

Ghiorso MS, Sack O (1991) Fe-Ti oxide geothermometry: thermodynamic formulation and the estimation of intensive variables in silicic magmas. Contrib Mineral Petr 108(4):485-510. https://doi.org/10. 1007/BF00303452

Ghiorso MS, Sack RO (1995) Chemical mass transfer in magmatic processes IV. A revised and internally consistent thermodynamic model for the interpolation and extrapolation of liquid-solid equilibria in magmatic systems at elevated temperatures and pressures. Contrib Mineral and Petr 119(2-3):197-212. https://doi.org/10.1007/ BF00307281

Grove TL, Baker MB, Kinzler RJ (1984) Coupled CaAl-NaSi diffusion in plagioclase feldspar: experiments and applications to cooling rate speedometry. Geochim Cosmochim Acta 48(10):2113-2121. https://doi.org/10.1016/0016-7037(84)90391-0

Grove TL, Donnelly-Nolan JM, Housh T (1997) Magmatic processes that generated the rhyolite of Glass Mountain, Medicine Lake Volcano, N. California. Contrib Mineral Petrol 127(3):205-223. https://doi. org/10.1007/s004100050276

Gutiérrez F, Parada MÁ (2010) Numerical modeling of time-dependent fluid dynamics and differentiation of a shallow basaltic magma chamber. J Petrol 51(3):731-762. https://doi.org/10.1093/ petrology/egp101

Hickey-Vargas R, Abdollahi MJ, Parada MA, López-Escobar L, Frey FA (1995) Crustal xenoliths from Calbuco volcano, Andean southern volcanic zone: implications for crustal composition and magmacrust interaction. Contrib Mineral Petr 119(4):331-344. https://doi. org/10.1007/BF00286933

Hildreth W (2004) Volcanological perspectives on Long Valley, Mammoth Mountain, and mono craters: several contiguous but discrete systems. J Volcanol Geotherm Res 136(3):169-198. https:// doi.org/10.1016/j.jvolgeores.2004.05.019

Holland T, Blundy J (1994) Non-ideal interactions in calcic amphiboles and their bearing on amphibole-plagioclase thermometry. Contrib Mineral Petrol 116(4):433-447. https://doi.org/10.1007/ BF00310910

Huber C, Bachmann O, Manga M (2009) Homogenization processes in silicic magma chambers by stirring and mushification (latent heat buffering). Earth Planet Sci Lett 283(1):38-47. https://doi.org/10. 1016/j.epsl.2009.03.029

Huber C, Bachmann O, Dufek J (2010a) The limitations of melting on the reactivation of silicic mushes. J Volcanol Geotherm Res 195(2):97105. https://doi.org/10.1016/j.jvolgeores.2010.06.006

Huber C, Bachmann O, Manga M (2010b) Two competing effects of volatiles on heat transfer in crystal-rich magmas: thermal insulation vs defrosting. J Petrol 51(4):847-867. https://doi.org/10.1093/ petrology/egq003

Irvine TNJ, Baragar WRAF (1971) A guide to the chemical classification of the common volcanic rocks. Can J Earth Sci 8(5):523-548. https://doi.org/10.1139/e71-055

Ivy DJ, Solomon S, Kinnison D, Mills MJ, Schmidt A, Neely RR (2017) The influence of the Calbuco eruption on the 2015 Antarctic ozone hole in a fully coupled chemistry-climate model. Geophys Res Lett 44:1-6. https://doi.org/10.1002/2016GL071925

Kent AJ, Darr C, Koleszar AM, Salisbury MJ, Cooper KM (2010) Preferential eruption of andesitic magmas through recharge filtering. Nat Geosci 3(9):631-636. https://doi.org/10.1038/ngeo924

Klohn E (1963) The February 1961 eruption of Calbuco volcano. B Seismol Soc Am 53(6):1435-1436

Koyaguchi T, Kaneko K (1999) A two-stage thermal evolution model of magmas in continental crust. J Petrol 40(2):241-254. https://doi.org/ 10.1093/petroj/40.2.241

Lahsen, A, Moreno, H, Varela, J, Munizaga, F, López, L (1985) Geología y riesgo volcánico del volcán Calbuco y centros eruptivos menores. Proy Canutillar, ENDESA-Univ Chile, Informe Técnico, 215p 
Lara, LE, Orozco, G, Amigo, Á, Silva, C (2011) Peligros Volcánicos de Chile, Servicio Nacional de Geología y Minería, Carta Geológica de Chile, Serie Geología Ambiental. No. 13:34, Mapa escala 1: 2.000.000. Santiago

Lasaga AC (1983) Geospeedometry: an extension of geothermometry. In: Saxena SK (ed) Kinetics and equilibrium in mineral reactions. In: Advances in physical geochemistry, vol. 3. Springer, New York, pp $81-114$

Le Bas ML, Maitre RL, Streckeisen A, Zanettin B (1986) IUGS subcommission on the systematics of igneous rocks. A chemical classification of volcanic rocks based on the total alkali-silica diagram. J Petrol 27(3):745-750. https://doi.org/10.1093/petrology/27.3.745

Leake BE, Woolley AR, Arps CES, Birch WD, Gilbert MC, Grice JD, Hawthorne FC, Kato A, Kisch HJ, Krivovichev VG, Linthout K, Laird J, Mandarino JA, Maresch WV, Nickel EH, Rock NMS, Schumacher JC, Smith DC, Stephenson NCN, Ungaretti L, Whittaker EJW, Youzhi G (1997) Nomenclature of amphiboles: report of the subcommittee on amphiboles of the International Mineralogical Association, Commission on New Minerals and Mineral Names. Can Mineral 35:219-246

Lohmar S, Parada M, Gutiérrez F, Robin C, Gerbe MC (2012) Mineralogical and numerical approaches to establish the preeruptive conditions of the mafic Lican ignimbrite, Villarrica volcano (Chilean southern Andes). J Volcanol Geotherm Res 235:55-69. https://doi.org/10.1016/j.jvolgeores.2012.05.006

López-Escobar L, Parada MÁ, Moreno H, Frey FA, Hickey-Vargas RL (1992) A contribution to the petrogenesis of Osorno and Calbuco volcanoes, Southern Andes $\left(41^{\circ} 00^{\prime}-41^{\circ} 30^{\prime} \mathrm{S}\right)$ : comparative study. Rev Geol Chile 19(2):211-226

López-Escobar L, Cembrano J, Moreno H (1995a) Geochemistry and tectonics of the Chilean southern Andes basaltic quaternary volcanism (37-46 ${ }^{\circ}$ S). Rev Geol Chile 22(2):219-234

López-Escobar L, Parada MÁ, Hickey-Vargas R, Frey FA, Kempton PD, Moreno H (1995b) Calbuco volcano and minor eruptive centers distributed along the Liquiñe-Ofqui fault zone, Chile $\left(41^{\circ}-42^{\circ} \mathrm{S}\right)$ : contrasting origin of andesitic and basaltic magma in the southern volcanic zone of the Andes. Contrib Mineral Pet 119:345-336. https://doi.org/10.1007/BF00286934

Marsh BD (1989) Magma chambers. Annu Rev Earth P1 Sc 17(1):439 472. https://doi.org/10.1146/annurev.ea.17.050189.002255

Marsh BD (1996) Solidification fronts and magmatic evolution. Mineral Mag 60(1):5-40. https://doi.org/10.1180/minmag.1996.060.398.03

Molina PG, Parada MÁ, Gutiérrez FJ, Ma C, Li J, Yuanyuan L, Reich M, Aravena Á (2015) Protracted late magmatic stage of the Caleu pluton (Central Chile) as a consequence of heat redistribution by diking: insights from zircon data and thermal modeling. Lithos 227:255268. https://doi.org/10.1016/j.lithos.2015.04.008

Moore A, Coogan LA, Costa F, Perfit MR (2014) Primitive melt replenishment and crystal-mush disaggregation in the weeks preceding the 2005-2006 eruption 9 $9^{\circ}$ 50 N, EPR. Earth Planet Sci Lett 403:1526. https://doi.org/10.1016/j.epsl.2014.06.015

Moreno H, Naranjo JA, Clavero J (2006) Generación de lahares calientes en el volcán Calbuco, Andes del sur de Chile $\left(41,3^{\circ} \mathrm{S}\right)$. In Actas XI Congreso Geológico Chileno 2:512-513

Morgado E, Parada MÁ, Contreras C, Castruccio A, Gutiérrez F, McGee L (2015) Contrasting records from mantle to surface of two nearby arc volcanic complexes: Caburgua-Huelemolle small eruptive centers and Villarrica volcano. J Volcanol Geotherm Res 306:1-16. https://doi.org/10.1016/j.jvolgeores.2015.09.023

Morgado E, Parada MÁ, Morgan DJ, Gutiérrez F, Castruccio A, Contreras C (2017) Transient shallow reservoirs beneath small eruptive centres: constraints from $\mathrm{Mg}-\mathrm{Fe}$ interdiffusion in olivine. J Volcanol Geotherm Res 347:327-336. https://doi.org/10.1016/j. jvolgeores.2017.10.002

Müller T, Dohmen R, Becker HW, Ter Heege JH, Chakraborty S (2013) $\mathrm{Fe}-\mathrm{Mg}$ interdiffusion rates in clinopyroxene: experimental data and implications for $\mathrm{Fe}-\mathrm{Mg}$ exchange geothermometers. Contrib Mineral Petr 166(6):1563-1576. https://doi.org/10.1007/s00410013-0941-y

Parada MÁ (1990) Composición de fenocristales en lavas en volcán Calbuco y sus implicancias en la historia temprana de cristalización. Actas XI Congreso Geológico Argentino 1:101-104

Parmigiani A, Huber C, Bachmann O (2014) Mush microphysics and the reactivation of crystal-rich magma reservoirs. J Geophys Res Solid Earth 119(8):6308-6322. https://doi.org/10.1002/2014JB011124

Passmore E, Maclennan J, Fitton G, Thordarson T (2012) Mush disaggregation in basaltic magma chambers: evidence from the AD 1783 Laki eruption. J Petrol 53(12):2593-2623. https://doi.org/10.1093/ petrology/egs061

Petit-Breuilh ME (1999) Cronología eruptiva histórica de los volcanes Osorno y Calbuco, Andes del Sur $\left(41^{\circ}-41^{\circ} 30^{\prime}\right.$ S $)$. Boletín no. 53. Servicio Nacional de Geología y Minería, $46 \mathrm{p}$

Putirka KD (2008) Thermometers and barometers for volcanic systems. Rev Mineral Geochem 69(1):61-120. https://doi.org/10.2138/rmg. 2008.69.3

Ridolfi F, Renzulli A (2012) Calcic amphiboles in calc-alkaline and alkaline magmas: thermobarometric and chemometric empirical equations valid up to $1,130{ }^{\circ} \mathrm{C}$ and $2.2 \mathrm{GPa}$. Contrib Mineral Petrol 163: 877-895. https://doi.org/10.1007/s00410-011-0704-6

Ridolfi F, Renzulli A, Puerini M (2010) Stability and chemical equilibrium of amphibole in calc-alkaline magmas: an overview, new thermobarometric formulations and application to subductionrelated volcanoes. Contrib Mineral Petrol 160(1):45-66. https:// doi.org/10.1007/s00410-009-0465-7

Romero JE, Morgavi D, Arzilli F, Daga R, Caselli A, Reckziegel F, Viramonte J (2016) Eruption dynamics of the 22-23 April 2015 Calbuco volcano (southern Chile): analyses of tephra fall deposits. J Volcanol Geotherm Res 317:15-29. https://doi.org/10.1016/j. jvolgeores.2016.02.027

Ruprecht P, Bachmann O (2010) Pre-eruptive reheating during magma mixing at Quizapu volcano and the implications for the explosiveness of silicic arc volcanoes. Geology 38(10):919-922. https://doi. org/10.1130/G31110.1

Sauerzapf U, Lattard D, Burchard M, Engelmann R (2008) The titanomagnetite-ilmenite equilibrium: new experimental data and thermo-oxybarometric application to the crystallization of basic to intermediate rocks. J Petrol 49(6):1161-1185. https://doi.org/10. 1093/petrology/egn021

Saunders KE, Morgan DJ, Baker JA, Wysoczanski RJ (2010) The magmatic evolution of the Whakamaru supereruption, New Zealand, constrained by a microanalytical study of plagioclase and quartz. J Petrol 51(12):2465-2488. https://doi.org/10.1093/petrology/egq064

Schleicher JM, Bergantz GW (2017) The mechanics and temporal evolution of an open-system magmatic intrusion into a crystal-rich magma. J Petrol 58:1059-1072. https://doi.org/10.1093/petrology/ egx 045

Sellés, D, Moreno, H (2011) Geología del Volcán Calbuco, Región de Los Lagos. Carta Geológica de Chile. Serie Geológica Básica, No. 130. Escala 1:50.000

SERNAGEOMIN (2015a) Reporte especial de actividad volcánica (REAV) - Región de los Lagos, 2015, Abril 22-18:00

SERNAGEOMIN (2015b) Reporte especial de actividad volcánica (REAV) - Región de los Lagos, 2015, Abril 22-20:45

SERNAGEOMIN (2015c) Reporte especial de actividad volcánica (REAV) - Región de los Lagos, 2015, Abril 23-10:30

SERNAGEOMIN (2015d) Reporte especial de actividad volcánica (REAV)-Región de los Lagos, 2015, Abril 23-01:10

SERNAGEOMIN (2015e) Reporte especial de actividad volcánica (REAV)—Región de los Lagos, 2015, Abril 22-22:30

SERNAGEOMIN (2015f) Reporte especial de actividad volcánica (REAV)—Región de los Lagos, 2015, Abril 22-17:30 
SERNAGEOMIN (2015g) Reporte especial de actividad volcánica (REAV) - Región de los Lagos, 2015, Abril 23-10.30

SERNAGEOMIN (2015h) Reporte especial de actividad volcánica (REAV) - Región de los Lagos, 2015, Abril 22

SERNAGEOMIN (2015i) Reporte especial de actividad volcánica (REAV)—Región de los Lagos, 2015, Abril-Volumen 4a

SERNAGEOMIN (2017) Red Nacional de Vigilancia Volcánica, Volcán Calbuco. http://www.sernageomin.cl/volcan-calbuco. Accessed 3 March 2019

SERNAGEOMIN - BRGM (1995) Carta metalogénica X Región Sur, Chile. Servicio Nacional de Geología y Minería, Informe Registrado IR-95-05 (Inédito), 4 tomos, Santiago

Shejwalkar A, Coogan LA (2013) Experimental calibration of the roles of temperature and composition in the Ca-in-olivine geothermometer at 0.1 MPa. Lithos 177:54-60. https://doi.org/10.1016/j.lithos.2013. 06.013

Spera FJ, Bohrson WA (2018) Rejuvenation of crustal magma mush: a tale of multiply nested processes and timescales. Am J Sci 318:90 140. https://doi.org/10.2475/01.2018.05

Stern CR, Moreno H, López-Escobar L, Clavero JE, Lara LE, Naranjo JA, Parada MÁ, Skewes MA (2007) Chilean Volcanoes. In: Moreno T, Gibbons W (eds) The geology of Chile. Geological Society of London, London, pp 149-180

Stormer JC (1983) The effects of recalculation on estimates of temperature and oxygen fugacity from analyses of multicomponent irontitanium oxides. Am Mineral 68:586-594

Sun SS, McDonough WS (1989) Chemical and isotopic systematics of oceanic basalts: implications for mantle composition and processes. Geol Soc Lond, Spec Publ 42(1):313-345. https://doi.org/10.1144/ GSL.SP.1989.042.01.19
Szymanowski D, Wotzlaw JF, Ellis BS, Bachmann O, Guillong M, von Quadt A (2017) Protracted near-solidus storage and pre-eruptive rejuvenation of large magma reservoirs. Nat Geosci 10:777-782. https://doi.org/10.1038/NGEO3020

Tašárová ZA (2007) Towards understanding the lithospheric structure of the southern Chilean subduction zone $\left(36^{\circ} \mathrm{S}-42^{\circ} \mathrm{S}\right)$ and its role in the gravity field. Geophys J Int 170(3):995-1014. https://doi.org/10. 1111/j.1365-246X.2007.03466.x

Thiele, R, Godoy, E, Parada, MÁ, Varela, J (1985) Estudio geológicoestructural regional y tectónico del drea Petrohué-Canutillar. Proyecto Petrohué-Canutillar, ENDESA-U. de Chile (unpublished report)

Valderrama, Ó, Franco, L, Gil-Cruz, F (2015) Erupción intempestiva del volcán Calbuco, Abril 2015, XIV Congreso Geológico Chileno, III, p. $91-93$

Van Eaton AR, Amigo Á, Bertin D, Mastin LG, Giacosa RE, González J, Valderrama Ó, Fontjin K, Behnke SA (2016) Volcanic lightning and plume behavior reveal evolving hazards during the April 2015 eruption of Calbuco volcano, Chile. Geophys Res Lett 43(7):3563-3571. https://doi.org/10.1002/2016GL068076

Watt SF, Pyle DM, Naranjo JA, Rosqvist G, Mella M, Mather TA, Moreno H (2011) Holocene tephrochronology of the Hualaihue region (Andean southern volcanic zone, $\sim 42^{\circ} \mathrm{S}$ ), southern Chile. Quatern Int 246(1):324-343. https://doi.org/10.1016/j.quaint.2011. 05.029 